\title{
Policing Nightlife
}

Nightlife is a place of both real and imagined risk, a 'frontier' (Melbin 1978) where apparent freedom and transgression are closely linked, and where regulation of leisure and collective intoxication has been diffused throughout an expanding network of state and private actors. This book explores Sydney's contemporary night-time economy as the product of an intersection of both local and global transformations, as policing comes to incorporate more and more 'private' personnel empowered to regulate 'public' drinking and nightlife.

Policing Nightlife focuses on the historical and social conditions, cultural meanings and regulatory controls that have shaped both public and private forms of policing and security in contemporary urban nightlife. In so doing, it reflects more broadly on global changes in the nature of contemporary policing and how aspects of neoliberalism and the ideal of the '24-hour city' have shaped policing, security and night-time leisure. Based on a decade of research and interviews with both police and doorstaff working in nightlife settings, it explores the effectiveness of policies governing policing and private security in the night-time economy in the context of media, political and public debates about regulation, and the gendered and highly masculine aspects of much of this work.

An accessible and compelling read, this book will appeal to students and scholars of criminology, policing, sociology and those interested in understanding the debates surrounding security, policing and contemporary urban nightlife.

Dr Phillip Wadds is Senior Lecturer in Criminology at UNSW, Sydney. His research is situated at the intersection of four interrelated themes: policing; nightlife and related leisure; alcohol and other drugs; and violence. $\mathrm{He}$ has spent the last decade undertaking ethnographic and field-based research examining various features of nightlife in Sydney with an enduring focus on its policing and regulation. 


\section{Routledge Studies in Crime, Security and Justice}

Edited by

Adam Edwards, Cardiff University

Gordon Hughes, Cardiff University

Reece Walters, Queensland University of Technology

Contemporary social scientific scholarship is being transformed by the challenges associated with the changing nature of, and responses to, questions of crime, security and justice across the globe. Traditional disciplinary boundaries in the social sciences are being disturbed and at times broken down by the emerging scholarly analysis of both the increasing merging of issues of 'crime' and 'security' and the unsettling of traditional notions of justice, rights and due process in an international political and cultural climate seemingly saturated by, and obsessed with, fear, insecurity and risk. This series showcases contemporary research studies, edited collections and works of original intellectual synthesis that contribute to this new body of scholarship both within the field of study of criminology and beyond to its connections with debates in the social sciences more broadly.

\section{Protests in the Information Age}

Social Movements, Digital Practices and Surveillance

Edited by Lucas Melgaço and Jeffrey Monaghan

\section{Intimate Partner Violence, Risk and Security}

Securing Women's Lives in a Global World

Edited by Kate Fitz-Gibbon, Sandra Walklate, Jude McCulloch and JaneMaree Maher

\section{Policing and Politicising Organised Crime \\ Monique Mann}

\section{Policing Nightlife}

Security, Transgression and Urban Order

Phillip Wadds

For more information about this series, please visit: www.routledge.com/ Routledge-Studies-in-Crime-Security-and-Justice/book-series/RSCSJ 


\title{
Policing Nightlife
}

\section{Security, Transgression} and Urban Order

\section{Phillip Wadds}

\author{
Routledge \\ 冎 Taylor \& Francis Group


First published 2020

by Routledge

2 Park Square, Milton Park, Abingdon, Oxon OXI4 4RN

and by Routledge

52 Vanderbilt Avenue, New York, NY 10017

Routledge is an imprint of the Taylor \& Francis Group, an informa business

(c) 2020 Phillip Wadds

The right of Phillip Wadds to be identified as author of this work has been asserted by him in accordance with sections 77 and 78 of the Copyright, Designs and Patents Act 1988.

All rights reserved. No part of this book may be reprinted or reproduced or utilised in any form or by any electronic, mechanical, or other means, now known or hereafter invented, including photocopying and recording, or in any information storage or retrieval system, without permission in writing from the publishers.

Trademark notice: Product or corporate names may be trademarks or registered trademarks, and are used only for identification and explanation without intent to infringe.

British Library Cataloguing-in-Publication Data

A catalogue record for this book is available from the British Library

Library of Congress Cataloging-in-Publication Data

A catalog record has been requested for this book

ISBN: 978-I-I38-48880-9 (hbk)

ISBN: 978-I-35I-03942-0 (ebk)

Typeset in Bembo

by Wearset Ltd, Boldon, Tyne and Wear 


\section{Contents}

List of figures

vi

List of tables

vii

Acknowledgements

viii

List of abbreviations

ix

1 Introduction

2 Urban drinking and disreputable leisure in Sydney

3 The history of policing and nightlife

4 Regulation, security and the night-time economy: the Sydney study

5 'Crossing the line into the danger zone': nightlife, crime and policing in the news

6 'It's not always pretty, but someone has to do it': private security in Sydney's night-time economy

7 'The city in bedlam': police views on Sydney's nighttime economy

8 There and back again? Drinking and the governance of Sydney nightlife 


\section{Figures}

2.1 Typical views of Australian pubs during six o'clock closing (two images)

2.2 New design - the impact of six o'clock closing on the barroom environment

5.1 Number of Articles in SMH and DT by Year and Publication - 'Drinking and Violence' 


\section{Tables}

4.1 Alcohol restrictions for violent venues, by venue level

5.1 Assaultive crime statistics recorded by NSW Police in

Kings Cross and the Sydney Local Government Area

between 2002 and 2012

6.1 Interview participants from the private security industry

7.1 Interview participants from NSW Police 


\section{Acknowledgements}

I acknowledge Aboriginal and Torres Strait Islander peoples as the first custodians of the lands and waters where I live and work. These are stolen lands. I pay my respects to Elders past and present.

I would like to thank the many people who have been a part of this work or made it possible.

First, to Stephen Tomsen - thank you for your invaluable guidance, mentorship, support and generosity in reading and providing detailed feedback throughout the writing of this book, but also for your unwavering support over my career to date.

To my colleagues at UNSW - thanks for keeping me sane and caffeinated. Special mentions to Nick Apoifis, Will Clapton, Charlotte Smedley and all my UNSW Criminology colleagues for your friendship and good humour, but mainly for keeping me distracted from all the noise in this mad world we work in.

I would also like to thank Peta Wolifson for her editorial assistance; Bryn for coming along on many field adventures; Brian for opening doors; Rhonda and Kevin Wadds for your constant interest, love and support; my brothers and their families for making everything a lot of fun; the Smiths for your constant interest, laughs and care; The Ducks for good banter and occasional exercise; and all the participants, gatekeepers, staff, assistants and assorted others who contributed to the various projects and works informing this book.

Finally, a massive thank you to Michelle and Grace. You let me do the work I love, and I am incredibly grateful. Thank you for your constant support and selflessness, and for putting up with an incredibly 'challenging' human during this process (and all other times). 


\section{Abbreviations}

$\begin{array}{ll}\text { A\&E } & \text { accident and emergency } \\ \text { ABS } & \text { Australian Bureau of Statistics } \\ \text { AHA } & \text { Australian Hotels Association } \\ \text { AOD } & \text { alcohol and other drugs } \\ \text { CBD } & \text { central business district } \\ \text { CCTV } & \text { closed-circuit television } \\ \text { CEO } & \text { chief executive officer } \\ \text { CIB } & \text { Criminal Investigation Branch } \\ \text { CoS } & \text { City of Sydney Council } \\ \text { DPP } & \text { Director of Public Prosecutions } \\ \text { DT } & \text { Daily Telegraph (NSW) } \\ \text { GD } & \text { general duties } \\ \text { LGA } & \text { local government area } \\ \text { NRL } & \text { National Rugby League } \\ \text { NSW } & \text { NSW } \\ \text { NSW BOCSAR } & \text { NSW Bureau of Crime Statistics and Research } \\ \text { NTE } & \text { night-time economy } \\ \text { OLGR } & \text { Office of Liquor Gaming and Racing } \\ \text { RSA } & \text { Responsible Service of Alcohol } \\ \text { RSL } & \text { Returned and Services League } \\ \text { SMH } & \text { Sydney Morning Herald } \\ \text { UK } & \text { The United Kingdom } \\ \text { US } & \text { The United States }\end{array}$




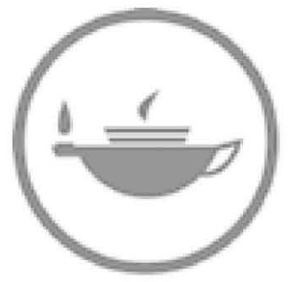

Taylor \& Francis Taylor \& Francis Group

http://taylorandfrancis.com 


\section{Chapter I}

\section{Introduction}

Summer 2009

$11.30 \mathrm{pm}$. Atop the escalator is your first glimpse of the neon highway that is Darlinghurst Road, the main artery of the notorious Kings Cross entertainment precinct. Two large billboards at the exit to the train station warn night-goers of the potential harms associated with binge drinking and drug consumption, a sentiment almost entirely lost on a crowd of consumers converging on the most popular site of mass intoxication Sydney has to offer....

It's $4 \mathrm{am}$. Throngs of inebriated revellers litter the gutters of Darlinghurst Road, their faces portraying a mix of confusion, exhaustion and discomfort. It's been a long night, and for all the wrong reasons. I have just finished being interrogated by police officers after a female patron at the bar I was drinking at was king-hit by a bouncer the size of a small car. The ensuing melee between the now hospitalised female patron's male friends and venue security didn't last long before Kings Cross police officers intervened, but what it lacked in length it made up for in ferocity. As an eye-witness to the whole affair you would think the police would be interested in my account of the incident; instead I was met with contempt by a series of officers who considered me just another drunken lout.

(excerpt from field notes - Wadds)

As the above fieldnote highlights, nightlife is a site of intense conflict and tension. In this urban space, there is sharp contradiction between hedonistic consumerism and state regulation that frequently results in clashes between revellers and both police and security staff. The situation in Sydney's nighttime economy (NTE) has been a mirror of a global urban problem (see Hobbs et al. 2003; Roberts et al. 2006; Winlow and Hall 2006; Hadfield 2009; Rigakos 2008; Calafat et al. 2010; Van Liempt and van Aalst 2012; Tomsen and Wadds 2016; Wadds 2019). Indeed, much has been written about the transgressive, violent and disorderly character of nightlife in the post-industrial city (Shepherd and Brickley 1996; Tomsen 1997, 2005, 2014a, 
2014b; Presdee 2000; Chatterton 2002; Monaghan 2002; Hobbs et al. 2003, 2005a, 2005b; Measham and Brain 2005; Jayne, Holloway and Valentine 2006; Hayward and Hobbs 2007; Eldridge and Roberts 2008; Fileborn 2016; Jayne, Valentine and Holloway 2016; Wadds 2019). Illicit drug consumption, binge drinking, interpersonal violence and social disorder feature frequently in nightlife hotspots and often shape public perceptions of safety and security in the city after dark (Wadds 2015). The politicisation of law and order has ensured that these offences have become issues of increasing electoral significance in contemporary developed nations. Accordingly, news media often engage in political agenda-setting around issues of transgression and urban order, while also acting as a facility through which politicians focus public attention towards matters of political importance and promote the efficacy of party policies (McCombs and Shaw 1972; Page, Shapiro and Dempsey 1987; Jewkes 2004; Greer 2007; Graber 2011). In Sydney, as around the world, such media campaigning has played a critical and central role in the development of inconsistent and often contradictory policy concerning the regulation, governance and policing of nightlife. Indeed, it will be an argument of this book that concern about nightlife often seems close to a form of a 'moral panic' (Cohen 1972), where distorted and negative impressions replicate and promote simplistic, 'commonsense' discussions of nightlife, safety and security.

In this context, police officers and an increasing number of private security staff combine to form a largely dysfunctional policing alliance. Public ambivalence about the role of doorstaff in nightlife settings, however, is tempered by the acknowledgement that public policing organisations lack the resources and operational capacity to provide an adequate and sustained presence in the NTE. As a result, public police have been increasingly dedicated to 'image work' (Mawby 2002), a strategy that seeks to placate community anxieties through large-scale and highly publicised 'blitzes' against a range of real and perceived social problems. In nightlife settings, these operations have been largely symbolic and have failed to provide adequate long-term solutions to issues of safety and security. It is the relationship between the two most prominent policing 'segments' (see Reich, Gordon and Edwards 1973) in Sydney's city after dark that is the focus of much of this book.

\section{Nightlife, transgression and security}

Nightlife has always been associated with danger, risk and concerns for personal safety. The absence of light and the recession of normative rhythms of day-time social activity has meant that night-time has often had ascribed to it an atmosphere of transgression - a 'frontier' (Melbin 1978, 1987) occupied by questionable characters engaged in disreputable activities. With the decline of industrial production, however, the role and structure of nightlife has been 
fundamentally altered by technological, socio-political and economic forces. These forces have transformed not only the context of social interaction and leisure in the post-industrial city, but also the nature of the state's role in key service provision and governance (Jessop 1997, 2002). This book focuses on changes in the character of contemporary policing at night that have been rooted in shifting modes of governance centrally driven by neoliberalism and new urban political structures.

Historically, routines of behaviour after dark were restricted by the absence of light (Melbin 1978, 1987). Technological developments in massproduced public lighting at the beginning of the 19th century, however, led to a reimagining of the city and an expansion of possibilities. Hours that were previously inaccessible to industrial production were made available by the development of lighting technology, greatly increasing the utility of the night. Melbin (1978: 14-15) stressed this point when he stated:

Night's riches [was] time itself. This form of natural wealth lured entrepreneurs to exploit the region for the profit opportunities it offered, and much of the dark's organized activity was evoked because of access to more time.... It is like an additive to the engine of production. As entrepreneurs were earlier drawn to newly accessible wealth in the land, they were now attracted to the promise of fortunes in the night.

With the advent of effective public lighting, night-time could feasibly be viewed as a promising if undeveloped resource or even a new economic 'frontier' that was ripe for exploitation by industrialism and capitalism. The economic potential of the night began to be realised in the early 19th century through the extended operating hours of factories, wharfs, packing and storehouses, leading to the evolution of multiple work 'shifts' (Melbin 1978).

Stable and efficient lighting enabled greater production, which in turn increased demand for working populations in rapidly expanding cities. These developments further fuelled the industrial revolution in many nations and fundamentally altered the condition of cities at night throughout the developed world. As time progressed, lighting also made the night available as a setting for more widespread leisure and consumption, a process that would transform the landscape of the city. Most importantly, the extension of permanent 'red-light', heavy drinking and vice-prone entertainment districts with a veiling semi-darkness extended old links between morally unconstrained leisure and the urban night (Mackey 1987; Hubbard 1998). Issues of public safety, security, criminal leisure and police corruption followed on from these changes and will be discussed in Chapter 3. In the 19th and 20th centuries, these concerns were most dramatically signalled by the mixed anxiety and allure of 'sin cities' such as Paris, New York, and pre-war Berlin and Shanghai, with a flourishing 'immoral' night-time sphere (De Leeuw 1934, 1943). Problems relating to night-time leisure, security and policing 
have again resurfaced in a new historical phase in urban development at the tail-end of industrial capitalism.

In the last four to five decades, with many nations restructuring as postindustrial societies, there has been another reimagining of the night based on economic, socio-political and cultural reform. With the decline of heavy industry, many states have focused on the potential of expanded leisure as a means of driving economic growth and social change (Lovatt and O'Connor 1995; Zukin 1991, 1995; Hannigan 1998; Hobbs et al. 2003). Central to these transformations has been the emergence and popularisation of neoliberal modes of governance and the construction of what is now known as the 'night-time economy'. Both these developments have shaped the planning, imaging and form of many post-industrial cities that increasingly compete for 'global' cosmopolitan or culturally significant status (Roberts and Eldridge 2012). Sydney is the Australian city where this title has been most fervently pursued.

The NTE refers to the range of leisure activities and experiences associated with collective night-time sociability and entertainment (Bianchini 1994; Lovatt and O'Connor 1995; Hannigan 1998; Rowe et al. 2008). The construction of the city at night as a 'night-time economy' emerged in Western Europe in the late 1980s and early 1990s against the backdrop of an emerging neoliberal discourse that was driven by the advance of market logic. This was a time when many cities in developed economies were suffering from the decline of heavy industry (Lovatt and O'Connor 1995; Hobbs et al. 2003). Without industrial production, many city spaces were left derelict and, subsequently, provided little economic utility to local, state and national governments. A new and innovative approach was required to reactivate and reinvigorate the local economies of these depressed city centres, factory districts and waterfronts.

The dissolution of highly structured routines of work and leisure towards the end of the 20th century provided urban planners with an opportunity to create more fluid and liberal urban spaces (Lash and Urry 1987, 1994). The increasing socio-economic importance of the leisure, tourism and service sectors also encouraged the idea that night-time leisure represented an underutilised resource. Indeed, it was believed that changing employment patterns, combined with increasing disposable income, would facilitate economic transition from production to consumption-based economies that would be driven by entrepreneurial private enterprise (Heath and Stickland 1997; Winlow and Hall 2006). This structural shift, combined with the desire to overcome negative perceptions of public safety and security in depressed city centres, and to encourage forms of night-time sociability modelled on continental Europe's ostensibly 'cosmopolitan' nightlife, led a range of British and European cities to foster the NTE as central to their urban revitalisation programs (Lovatt 1994; Lovatt and O’Connor 1995; Bianchini 1995; Hobbs et al. 2003; Tierney 2006; Roberts 2009). Conceptions of the '24-hour city' 
provoked more inclusive and expansive consideration of the entire city centre, developing the city after dark into a 'brand' that could improve city image and attract significant inward investment (Lovatt and O'Connor 1995; Heath and Stickland 1997; Roberts and Eldridge 2012). As a result of these transformative forces, nightlife was again reconceived, reimaged and promoted as central to the experience and value of the modern city. In this regard, contemporary nightlife is a product, commodified and advertised as a site of liminal freedoms removed from restrictive day-centric routines. Cities now openly compete for status as 'nightlife destinations' and 'global cities' with elaborate night 'culture', competition which has often had marked repercussions for urban governance and even greater implications for state revenue. Many changes in nightlife policy and governance have also had significant and ongoing effects on levels of safety, access, inclusion and, consequently, diversity in city many spaces, serving to homogenise and sanitise the urban night-time experience while marginalising specific populations deemed less desirable or profitable (Talbot 2016; Wolifson and Drozdzewski 2017).

These changes have been consistent with the emergent neoliberal discourse that was driven from the late 1970s by the policies of Thatcher and Reagan and became prominent around the same time as post-industrial decline began to affect many Western nations (see Harvey 2007 for an overview). Indeed, these policies played a central role in accelerating the decline in manufacturing and industrial production that had been the economic backbone of many industrial nations since the early 1800s. Neoliberalism advocates a central focus on free-markets, marketisation, individual selfreliance, privatisation and cuts to welfare and service provision by the state (Amin and Malmberg 1994; Jessop 1997, 2002; Fourcade-Gourinchas and Babb 2002; Harvey 2007). Under the direction of neoliberalism, state institutions have been 'hollowed out' (Newburn 2001; Jessop 1997, 2002) and have assumed greater audit and regulatory capacities at the expense of public service and welfare delivery (Harvey 2007). Neoliberal governance has placed considerable focus on shoring up revenue sources and is frequently typified by short-term and inconsistent policy-making in which considerations of social wellbeing are subordinated to fundamental guarantees of private profit (Jessop 1997, 2002; Fourcade-Gourinchas and Babb 2002; Harvey 2007). In retrospect, the planning and implementation of strategies and policies concerning night-time revitalisation, certainly in Sydney, have followed this neoliberal pathway, often at the expense of coherent public policy. Under these circumstances, it has been vital to reconcile the needs of public safety and security with the limited resources and capabilities of state and private policing bodies in dealing with collective drinking and the associated threat of public disorder and violence.

In Sydney and elsewhere, until recently, utopian conceptions of 'cosmopolitan' NTEs based on 'civilised', 'inclusive' and 'culturally diverse' sociality have run in tandem with deregulation of liquor licensing and a major expansion of 
public night-time drinking. Subsequently, many deliberately stimulated urban NTEs have come to be dominated by problematic alco-leisure (Hadfield et al. 2001; Hadfield 2009; Measham and Brain 2005; Hayward and Hobbs 2007; Eldridge and Roberts 2008). Hadfield et al. (2001: 1) reflected upon the failures of the NTE concept in achieving its 'civilising' process when they bluntly stated that the 24-hour city has come to be dominated by the violent and unruly "mass volume vertical drinker" whose belligerent behaviour has left urban nightlife precincts awash with litter, vomit and urine, a sight that is far from the vision imagined by early NTE advocates and city planners. Complicating issues of nightlife disorder is the fact that tax revenue from alcohol and gambling has rested behind the expansion of the NTE in many cities. In both the United Kingdom and Australia, policy-makers and planners have often been attracted to liberalised alcohol licensing and policy due to the liquor industry's ability to generate considerable revenue streams (Chatterton 2002; Hobbs et al. 2003; Hayward and Hobbs 2007; Tomsen and Wadds 2016). This reality has had both public and private impacts. Most notably, it has led to an increase in the number and density of licensed venues in nightlife hotspots.

The impact of market liberalisation and poor regulatory management on city safety and amenity has been stark, and the situation in Sydney and many other major cities in the early 2000 s often seemed to reflect this. Indeed, research has frequently demonstrated the link between liberalisation of alcohol licensing and sharp rises in assaultive crime and disorder (Homel and Tomsen 1993; Briscoe and Donnelly 2001; Gorman et al. 2001; Chikritzhs and Stockwell 2002; Hall and Winlow 2005; Donnelly et al. 2006; Hayward and Hobbs 2007; Livingston 2008; Campbell et al. 2009) and commensurate increases in night-time accident and emergency admissions (Tatlow, Clapp and Hohman 2000; Miller et al. 2011, 2015; Cherpitel et al. 2015; Liu et al. 2016). The presence and growth of illicit markets in booming nightlife spaces should also be noted when discussing the crime/violence nexus and is discussed throughout this book.

Further perpetuating a sense of patron vulnerability to harm in nightlife settings, media coverage of nightlife violence and disorder belies statistical evidence as to the true likelihood of victimisation (Wadds 2015, 2019), particularly in relation to crimes of a very violent and sexual character (Lundman 2003; Jewkes 2004; Ditton 2005; Potter and Kappeler 2006; Greer and Reiner 2015; Jewkes and Linneman 2017). Noting this does not deny that violence is a real issue in nightlife settings - of course it is - but that the level and type of media reporting has often undermined the development of reasoned, evidence-based policy.

Despite frequent media exaggeration, good evidence does confirm that the after-dark hours host a significant volume of criminal activity including interpersonal and violent crime (Laslett et al. 2010; Miller et al. 2013; Fileborn 2016; Pedersen et al. 2016; Tomsen 2018) and that alcohol and other drug (AOD) use has a central place in this (for an overview of issues relating to 
AOD consumption, incivility, violence and disorder see Graham and Homel 2008). In fact, according to a study conducted by Collins and Lapsley (in 2008), the estimated cost of alcohol to the community in Australia was approximately $\$ 15$ billion per annum, which included costs associated with crime, violence, treatment costs, loss of productivity and premature death. Sydney, as Australia's largest and most populous city, has long been positioned at the epicentre of public anxiety and political debate concerning the regulation of this highly contentious commodity.

While the consumption of alcohol has different individual, collective and situational effects, there is strong evidence of its generally frequent 'criminogenic' character in night leisure (Wells and Graham 2003; Miller et al. 2013). High alcohol consumption has been shown to reduce an individual's cognitive and verbal capacity to resolve conflict, thereby increasing the likelihood of involvement in aggravated verbal exchange and physical violence (Buss, Abdu and Walker 1995; Borges et al. 2006; Australian Bureau of Statistics 2007; National Health and Medical Research Council 2009). Further, AOD consumption has been identified as a major factor in three-quarters of assaults and offensive behaviour at street level (Buss, Abdu and Walker 1995), around a third of all violent crime (Laslett et al. 2010), and as a significant contributor to homicides (Tomsen 2018), assaults (BOCSAR 2018) and sexual violence in commercial leisure settings in Australia (Fileborn 2016; Fileborn, Wadds and Barnes 2019; Fileborn, Wadds and Tomsen 2019).

Contradictions between liquor industry demands, public planning needs, the expansion of night-time drinking leisure and policing and safety requirements have all surfaced as a result of the competing pressures that exist within the NTE. In New South Wales (NSW), all these pressures are apparent when analysing the condition of local nightlife. Accordingly, growth of night-time drinking-related leisure has occurred against a backdrop of very uneven and divided planning, frequently without adequate policing, security, regulatory and governance frameworks.

Compounding these issues is the fact that public policing institutions alone do not have the capacity or resources to properly regulate this social sphere (Tomsen and Wadds 2016; Wadds 2019). In line with neoliberal policies of minimising state-based service provision, public policing is increasingly supplemented or assumed by private actors in an attempt to moderate governmental expenditure and more easily regulate this risky terrain. The dramatic growth in the private security sector in relation to the NTE has meant that doorstaff and venue security are now the primary security providers in most cities at night (Hobbs et al. 2003; Prenzler, Sarre and Earle 2008; Rigakos 2008; Wadds 2015). In fact, Rigakos (2008) suggested that in nightlife settings in Halifax, Canada, private security personnel outnumbered police by ten to one. A similar estimate was given by Hobbs et al. (2003) for the situation of night-time policing in Manchester and other British cities in the early 2000s. This process of expanding private security has been one of the most 
significant developments for contemporary research on urban crime and safety, and debates about the surveillance and regulation of city space. Australian developments have also signalled the importance of this transition, although many aspects of the local changes are still yet to be examined in detail.

The role of private security has undergone profound change and reform in the post-industrial city, alongside significant changes in the nature of policing (Shearing and Stenning 1983; Johnston 1992, 1999, 2003; Bayley and Shearing 1996; Loader 1997, 2000; Newburn 2001; Jones and Newburn 2002; Crawford et al. 2005; Crawford 2012; Wakefield 2012; Rogers 2016; Bradley 2017). From its origins as a largely unsupervised and poorly trained group of men engaged in private guard duties, the private security industry has developed into a complex, diversified and unevenly regulated industry. This occupational transformation has occurred within a relatively brief period of time and has been rife with difficulties. Many problems have (re)surfaced throughout the industry's new expansion into the urban night realm, with involvement in criminal activity and a lack of sufficient regulation governing the use of force by industry employees. These flaws have often been the catalyst for occupational reform in the private security industry. In fact, 'bouncer' violence has often been a key negative marker of what critics of expanded NTEs see as exemplifying the new dangers of their further growth.

Most notable in Australia in this regard was the 2004 death of former Australian cricketer, David Hookes, who was fatally assaulted by a security guard at a Melbourne nightspot (Schwarz 2006; Wadds 2011). His death sparked widespread outrage concerning the lack of regulation governing private security and generated pressure in Victoria and other states to revise legislation and policy regarding the industry. Similar Sydney-based incidents involving doormen and venue controllers have contributed to significant public concern about poor regulation of nightlife and the transference of roles that traditionally fell with state-employed public police. High-profile incidents in Sydney have included the shooting of a guard involved in illicit drug dealing at the Blackmarket nightclub in 1997 (Brown and Kennedy 1997), the death of Peter Dalamangas at Sydney's Star City Casino in 1998 (Goodsir et al. 1998; Clennell 1998a, 1998b), the 2004 bashing of Rodrigo Grveno outside a popular Sydney nightclub (Wallace 2004) and the killing of Wilson Duque Castillo following an altercation with venue security in Kings Cross in 2010 (Coote 2011; Fife-Yeomans 2011; O’Malley 2011).

Over almost 20 years (between 1990 and 2009), a period of which the empirical core of this book covers, Sydney night revellers witnessed a significant deregulation of trading hours, an increase in the number of licensed venues and locations, and growing organised crime wars in popular nightlife precincts. Alongside, or perhaps because of, concerns about corruption, NSW Police were in part sidelined from the regulation of this domain (with the temporary abolition of (liquor) licensing officers) and then re-involved in 
new ways to placate public anxieties about violence, organised crime and disorder associated with urban night leisure (Fleming 2008). Indeed, the public and media furore over the 2011 group security guard bashing of a young male patron in the very briefly closed 'upmarket' Ivy nightclub (Howden et al. 2011; Olding et al. 2011) underscored how full venue closure was a very unusual circumstance in a previous era of generally expanded access to drink and increased taxable consumption.

In more recent years, however, a number of high-profile alcohol-related deaths in major urban nightlife precincts have resulted in wide-ranging changes in the regulation of nightlife in Sydney. These changes, packaged and delivered by the NSW Government as the Plan of Management for the Sydney CBD Entertainment Precinct, included the introduction of $1.30 \mathrm{am}$ 'lockouts' (a one-way door policy) and 3.00 am cessation of service in two designated nightlife 'zones' in the city (Kings Cross and Sydney CBD) alongside a series of other tenuously related and often poorly conceived legislative amendments that reflected an extraordinary shift in the political treatment of the NTE. Popularly known as the 'lockout laws', these policy interventions polarised locals and set off a longstanding debate about what 'right' people should have to access drinking leisure in the city at night (Lee 2016; Race 2016). Set within an historical frame, however, the lockout laws appear less exceptional as a mechanism for regulating 'unruly' nightlife, and, in fact, follow a relatively regular pattern of policy fluctuation in NSW - and indeed Australian - history. That said, they remain a remarkable case study of contemporary local politics and the competing ideological and economic forces that rest behind particular ways of governing.

It is suggested in this book that the policy contestation between local and state government, the liquor and music industries, licensees and venue owners, security providers, health officials and local planning authorities has created a patchwork of interests and objectives that has left Sydney's public police in a situation where they must appear, but very often fail, to balance the mobilised interests of industry, night users, vulnerable groups and local residents. With limited resources to meet the pressures of this task, police have favoured the adoption of high-profile, media-directed and highly symbolic campaigns against night crime with often unproven effects on levels of offending and perceptions of public safety.

The empirical core of this book is based on a number of detailed and immersive studies of Sydney nightlife conducted since 2008 and the author's more recent involvement in policy development and discussion concerning Sydney's NTE. These research projects have focused on active nightlife sites across Australia's largest city, Sydney, and included ethnographic fieldwork and in-depth interviews with revellers, police, security and other key stakeholders involved in the regulation and governance of these spaces. Mapping discourse from observations and in-depth interviews provides new insight into the impact of changes to regulation in nightlife settings, and sheds light 
on various public and state inquiries and an ostensible 'professionalisation' of both the public police and private security. Interviews were aimed at uncovering subjective understandings of safety, security and regulation in nightlife and were juxtaposed with data from historical accounts of earlier policy debates, media reports, official evidence about the policing and governance of nightlife, and how each of these sources related to the lived experience and regulation of Sydney's urban NTE in the long term.

\section{Structure of the book}

This book is divided into three parts. The first section details the complex and volatile histories concerning the regulation and policing of alcohol, drinking and nightlife since colonisation of Australia and how they have shaped the nature and governance of contemporary nightlife.

The second section examines the contemporary NTE, its local manifestation and the issues of law and order that have dominated recent debates about the urban night. It explores the emergence of the 'night-time economy' as a central framing concept in the organisation of the contemporary urban night and its failure in Sydney (and similar urban sites) to deliver on its promise of a culturally diverse, dynamic, inclusive and safe nightlife. In doing so, it examines the contradictory role that public debates, political comment and the media have played in shaping 'city image' and developments related to urban nightlife, crime and policing in the past two decades. Finally, this section discusses the way policing, in both public and private forms, has been represented in media discourse around nightlife, and the way in which state police have used the media as a facility to foster positive public imagery and legitimise a range of high-profile campaigns around the policing of alcohol-related violence and disorder.

The third, and final, section of this book introduces and analyses field interviews and observations involving private security staff and police working in Sydney's key night-time leisure precincts. ${ }^{1}$ It explores the changing character of policing and the impact this has had on broader issues of urban safety, conflict, violence and a public sense of (in)security after dark. It also unpacks the complex role that masculinities and masculine performance play in the persistence of an aggressive culture in policing and security operating in nightlife spaces. Moreover, it explores aspects of occupational change in relation to this work as it relates to masculinity and notions of bodies, danger, force and violence, as well the impact that the growth and regulation of the NTE have had on occupational practices and sentiment. The wider implications of these work practices for city surveillance and regulation are also considered. Finally, it discusses the working relationship between security and police in nightlife settings, including analysis of the status challenges inherent to the relationship and the impact these have on efforts to cooperate, coordinate and enhance 'policing' in the city after dark. 


\section{Note}

1 Throughout this book, pseudonyms have been used for all participants and venues to ensure anonymity.

\section{References}

Amin, A. and Malmberg, A. (1994) 'Competing Structural and Institutional Influences on the Geography of Production in Europe', in A. Amin (ed.), Post-Fordism: A Reader. Oxford: Blackwell.

Australian Bureau of Statistics (2007) 'Australian Social Trends, 2007: Interpersonal Violence'. Canberra: Australian Government Publishing Service.

Bayley, D.H. and Shearing, C.D. (1996) 'The Future of Policing'. Law and Society Review, 30(3): 585-606.

Bianchini, F. (1994) 'Night Cultures, Night Economies'. Town and Country Planning, 63(11): 308-310.

Bianchini, F. (1995) 'Night Cultures, Night Economies'. Planning Practice and Research 10(2): 121-126.

BOCSAR (2018) 'Alcoho-related Violence'. Available online at: www.bocsar.nsw.gov. au/Pages/bocsar_pages/Alcohol_Related_Violence.aspx. Accessed 20 October 2019.

Borges, G., Cherpitel, C., Orozco, R., Bond, J., Ye, Y. and Macdonald S. (2006) 'Multicentre Study of Acute Alcohol Use and Non-fatal Injuries: Data from the WHO Collaborative Study on Alcohol and Injuries'. Bulletin of the World Health Organization, 84(6): 453-460.

Bradley, T. (2017) 'The Pluralisation of Policing', in A. Deckert and R. Sarre (eds), The Palgrave Handbook of Australian and New Zealand Criminology, Crime and Justice. Cham: Palgrave Macmillan, pp. 497-510.

Briscoe, S. and Donnelly, N. (2001) 'Assaults on Licensed Premises in Inner-urban Areas'. Alcohol Studies Bulletin no. 1, NSW Bureau of Crime Statistics and Research.

Brown, M. and Kennedy, L. (1997) 'Day the Bandidos Brotherhood Travelled the Hardest Road in Silence', Sydney Morning Herald, 14 November 1997, p. 7.

Buss, T.F., Abdu, R. and Walker, J.R. (1995) 'Alcohol, Drugs and Urban Violence in a Small City Trauma Center'. Journal of Substance Abuse Treatment, 12(2): 75-83.

Calafat, A., Blay, N. T., Hughes, K., Bellis, M., Juan, M., Duch, M. and Kokkevi, A. (2010) 'Nightlife Young Risk Behaviours in Mediterranean versus Other European Cities: Are Stereotypes True?'. The European Journal of Public Health, 21(3): 311-315.

Campbell, C.A., Hahn, R.A., Elder, R., Brewer, R., Chattopadhyay, S., Fielding, J., Naimi, T.S., Toomey, T., Lawrence, B., Middleton, J.C. and Task Force on Community Preventive Services. (2009). 'The Effectiveness of Limiting Alcohol Outlet Density as a Means of Reducing Excessive Alcohol Consumption and Alcohol-related Harms'. American Journal of Preventive Medicine, 37(6): 556-569.

Chatterton, P. (2002) 'Governing Nightlife: Profit, Fun and (Dis)Order in the Contemporary City’. Entertainment Law, 1 (2): 23-49.

Cherpitel, C.J., Ye, Y., Bond, J., Borges, G. and Monteiro, M. (2015) 'Relative Risk of Injury from Acute Alcohol Consumption: Modeling the Dose-response Relationship in Emergency Department Data from 18 Countries'. Addiction, 110(2): 279-288. 
Chikritzhs, T. and Stockwell, T. (2002) 'The Impact of Later Trading Hour for Australian Public Houses (Hotels) on Levels of Violence'. Journal of Studies on Alcohol, 63: 591-599.

Clennell, A. (1998a) 'Police Check Security Video of Fatal Brawl at Star City Casino’, Sydney Morning Herald, 2 February 1998, p. 2.

Clennell, A. (1998b) 'Actor Supports Family Over Casino Death', Sydney Morning Herald, 3 February 1998, p. 3.

Cohen, S. (1972) Folk Devils and Moral Panics: The Creation of the Mods and Rockers. St Albans: Paladin.

Collins, D.J. and Lapsley, H.M. (2008) 'The Cost of Tobacco, Alcohol and Illicit Drug Abuse to Australian Society in 2004/05'. Canberra: Department of Health and Ageing.

Coote, A. (2011) 'The Fatal Footage - CCTV Shows Bashed Father Playing the Peacemaker', Daily Telegraph, 6 January 2011, p. 9.

Crawford, A. (2012) 'Plural Policing in the UK: Policing Beyond the Police', in T. Newburn (ed.) The Handbook of Policing (2nd Edition). London: Willan, pp. 175-209.

Crawford, A., Lister, S., Blackburn, S. and Burnett, J. (2005) Plural Policing: The Mixed Economy of Visible Patrols in England and Wales. Bristol: Policy Press.

De Leeuw, H. (1934) Sinful Cities of the Western World. New York: Citadel Press.

De Leeuw, H. (1943) Cities of Sin. New York: Willey Book Co.

Ditton, J. (2005) 'Crime and Fear in the Media'. Criminal Justice Matters, 59(1): 4-5.

Donnelly, N., Poynton, S., Weatherburn, D., Bamford, E. and Nottage, J. (2006) 'Liquor Outlet Concentrations and Alcohol-related Neighbourhood Problems'. Alcohol Studies Bulletin no. 8, NSW Bureau of Crime Statistics and Research.

Eldridge, A. and Roberts, M. (2008) 'A Comfortable Night Out? Alcohol, Drunkenness and Inclusive Town Centres'. AREA, 40(3): 365-374.

Fife-Yeomans, J. (2011) 'Painful Decision to End a Dad's Life', Daily Telegraph, 3 January 2011, p. 1.

Fileborn B. (2016) Reclaiming the Night-time Economy: Unwanted Sexual Attention in Pubs and Clubs. London: Palgrave Macmillan.

Fileborn, B., Wadds, P. and Barnes, A. (2019) 'Setting the Stage for Sexual Assault: The Dynamics of Gender, Culture, Space and Sexual Violence at Live Music Events', in S. Raine and C. Strong (eds), Towards Gender Equality in the Music Industry Education, Practice and Strategies for Change. London: Bloomsbury Academic, pp. 89-102.

Fileborn, B., Wadds, P. and Tomsen, S. (2019) 'Safety and Sexual Violence at Australian Music Festivals: Final Report'. Available online at: http://dx.doi.org/10. 13140/RG.2.2.30091.85280

Fleming, J. (2008) 'Rules of Engagement: Policing Anti-Social Behaviour and Alcohol-Related Violence in and Around Licensed Premises'. Sydney: NSW Bureau of Crime Statistics and Research.

Fourcade-Gourinchas, M. and Babb, S.L. (2002) 'The Rebirth of the Liberal Creed: Paths to Neoliberalism in Four Countries'. American Journal of Sociology, 108(3): 533-579.

Goodsir, D., Gimore, H. and Crittle, S. (1998) 'Casino Death "Now Murder Case", Sun Herald, 8 February 1998, p. 8. 
Gorman, D.M., Speer, P.W., Greunewald, P.J. and Labouvie, E.W. (2001) 'Spatial Dynamics of Alcohol Availability, Neighborhood Structure and Violent Crime'. Journal of Studies on Alcohol, 62: 628-636.

Graber, D.A. (ed.) (2011) Media Power in Politics (6th Edition). Washington, DC: CQ Press.

Graham K. and Homel, R. (2008) Raising the Bar: Preventing Aggression in and Around Bars, Pubs and Clubs. Devon: Willan Publishing.

Greer, C. (2007) Crime and Media: A Reader. New York: Routledge.

Greer, C. and Reiner, R. (2015). 'Mediated Mayhem: Media, Crime and Criminal Justice', in M. Maguire, R. Morgan and R. Reiner (eds), Oxford Handbook of Criminology (Fifth Edition). Oxford: Oxford University Press, pp. 245-278.

Hadfield, P. (2009). Nightlife and Crime: Social Order and Governance in International Perspective. Oxford: Oxford University Press.

Hadfield, P., Lister, S., Hobbs, D. and Winlow, S. (2001) 'The "24 Hour City" Condition Critical?'. Town and Country Planning, 70(11): 300-302.

Hall, S. and Winlow, S. (2005) 'Night-time Leisure and Violence in the Breakdown of the Pseudo-Pacification Process'. Probation Journal, 52(4): 376-389.

Hannigan, J. (1998) Fantasy City: Pleasure and Profit in the Postmodern Metropolis. London, Routledge.

Harvey, D. (2007) A Brief History of Neoliberalism. Oxford: Oxford University Press.

Hayward, K. and Hobbs, D. (2007) 'Beyond the Binge in "Booze Britain": Marketled Liminalization and the Spectacle of Binge Drinking'. British Journal of Sociology, 58(3): 437-456.

Heath, T. and Stickland, R. (1997) 'The Twenty-four-hour City Concept', in T. Oc and S. Tiesdell (eds), Safer City Centres: Reviving the Public Realm. London: Paul Chapman Publishing.

Hobbs, D., Hadfield, P., Lister, S. and Winlow, S. (2003) Bouncers: Violence and Governance in the Night-time Economy. Oxford: Oxford University Press.

Hobbs, D., Hadfield, P., Lister, S. and Winlow, S. (2005a) 'Violent Hypocrisy: Governance and the Night-time Economy'. European Journal of Criminology, 2(2): 161-183.

Hobbs, D., Hadfield, P., Lister, S. and Winlow, S. (2005b) 'Violence and Control in the Night-time Economy'. European Journal of Crime, Criminal Law and Criminal Justice, 13(1): 89-102.

Homel, R. and Tomsen, S. (1993) 'Hot Spots for Violence: The Environment of Pubs and Clubs', in H. Strang and S. Gerull (eds), Homicide: Patterns, Prevention and Control: Proceedings of a Conference Held 12-14 May, 1992. Canberra, Australian Institute of Criminology.

Howden, S., Olding, R. and Hall, L. (2011) 'Cage Fighter Charged Over "Vicious" Ivy Assault', Sydney Morning Herald, 30 August 2011, p. 1.

Hubbard, P. (1998) 'Sexuality, Immorality and the City: Red-light Districts and the Marginalisation of Female Street Prostitutes'. Gender, Place and Culture, 5(1): 55-72. Jayne, M., Holloway, S.L. and Valentine, G. (2006) 'Drunk and Disorderly: Alcohol, Urban Life and Public Space', Progress in Human Geography, 30(4): 451-468.

Jayne, M., Valentine, G. and Holloway, S.L. (2016). Alcohol, Drinking, Drunkenness:(Dis) orderly Spaces. Oxon: Routledge. 
Jessop, B. (1997) 'The Entrepreneurial City: Reimaging Localities, Redesigning Economic Governance or Restructuring Capital', in N. Jewson and S. MacGregor (eds), Transforming Cities: Contested Governance and New Spatial Divisions. New York: Routledge.

Jessop, B. (2002) 'Liberalism, Neoliberalism, and Urban Governance: A StateTheoretical Perspective'. Antipode, 34(3): 452-472.

Jewkes, Y. (2004) Media and Crime. London: Sage.

Johnston, L. (1992) The Rebirth of Private Policing. London: Routledge.

Johnston, L. (1999) 'Private Policing in Context'. European Journal on Criminal Policy and Research, 7(2): 175-196.

Johnston, L. (2003) 'From "Pluralisation" to "the Police Extended Family": Discourses on the Governance of Community Policing in Britain'. International Journal of the Sociology of Law, 31: 185-204.

Jones, T.T. and Newburn, T. (2002) 'The Transformation of Policing? Understanding Current Trends in Policing Systems'. British Journal of Criminology, 42(1): 129-146.

Lash, S. and Urry, J. (1987) The End of Organised Capitalism. Cambridge: Polity Press.

Lash, S. and Urry, J. (1994) Economies of Signs and Space. Thousand Oaks: Sage.

Laslett, A.M., Catalano, P., Chikritzhs, T., Dale, C., Doran, C., Ferris, J. and Wilkinson, C. (2010) The Range and Magnitude of Alcohol's Harm to Others. Fitzroy, Victoria, Australia: AER Centre for Alcohol Policy Research, Turning Point Alcohol and Drug Centre, Eastern Health.

Lee, M. (2016). Sydney's Lockout Laws: For and Against. Current Issues in Criminal Justice, 28(1): 117-121.

Liu, T., Ferris, J., Higginson, A. and Lynham, A. (2016) 'Systematic Review of Australian Policing Interventions to Reduce Alcohol-related Violence - A Maxillofacial Perspective'. Addictive Behaviors Reports, 4: 1-12.

Livingston, M. (2008). Alcohol Outlet Density and Assault: A Spatial Analysis. Addiction, 103(4): 619-628.

Loader, I. (1997) 'Private Security and the Demand for Protection in Contemporary Britain'. Policing and Society, 7: 143-162.

Loader, I. (2000) 'Plural Policing and Democratic Governance', Social and Legal Studies, 9(3): 323-345.

Lovatt, A. (1994) 'Cultural Identity Through the Night-time Economy', in A. Lovatt, J. O'Connor, J. Montgomery and P. Owens (eds), The 24-Hour City: Selected Papers from the First National Conference on the Night-time Economy. Manchester: Manchester Metropolitan University, pp. 29-39.

Lovatt, A. and O'Connor, J. (1995) 'Cities and the Night-time Economy', Planning Practice and Research, 10(2): 127-133.

Lundman, R.J. (2003) 'The Newsworthiness and Selection Bias in News about Murder: Comparative and Relative Effects of Novelty and Race and Gender Typifications on Newspaper Coverage of Homicide'. Sociological Forum, 18(3): 357-386.

Mackey, T.C. (1987) Red Lights Out: A Legal History of Prostitution, Disorderly Houses and Vice Districts, 1870-1917. London: Taylor and Francis.

Mawby, R.C. (2002) Policing Images: Policing, Communication and Legitimacy. Devon: Willan Publishing. 
McCombs, M.E. and Shaw, D.L. (1972) 'The Agenda-setting Function of Mass Media'. Public Opinion Quarterly, 36(2): 176-187.

Measham, F. and Brain, K. (2005) " "Binge" Drinking, British Alcohol Policy and the New Culture of Intoxication'. Crime, Media, Culture, 1(3): 262-283.

Melbin, M. (1978) 'Night as Frontier'. American Sociological Review, 43(1): 3-22.

Melbin, M. (1987) Night as Frontier: Colonizing the World After Dark. New York: The Free Press.

Miller, P., Sønderlund, A., Coomber, K., Palmer, D., Gillham, K., Tindall, J. and Wiggers, J. (2011) 'Do Community Interventions Targeting Licensed Venues Reduce Alcohol-related Emergency Department Presentations?'. Drug and Alcohol Review, 30(5): 546-553.

Miller, P., Droste, N., Baker, T. and Gervis, C. (2015) 'Last Drinks: A Study of Rural Emergency Department Data Collection to Identify and Target Community Alcohol-related Violence'. Emergency Medicine Australasia, 27(3): 225-231.

Miller, P., Pennay, A., Droste, N., Jenkinson, R., Quinn, B., Chikritzhs, T., Tomsen, S., Wadds, P., Jones, S., Palmer, D., Barrie, L., Lam, T., Gilmore, W. and Lubman, D. (2013) Patron Offending and Intoxication in Night-time Entertainment Districts (POINTED): Final Report. Melbourne: NDLERF.

Monaghan, L.F. (2002) 'Regulating "Unruly Bodies": Work Tasks, Conflict and Violence in Britain's Night-time Economy'. British Journal of Sociology, 53(3): 403-429.

National Health and Medical Research Council. (2009) 'Australian Guidelines to Reduce Health Risks from Drinking Alcohol'. Canberra: NHMRC.

Newburn, T. (2001) 'The Commodification of Policing: Security Networks in the Late Modern City'. Urban Studies, 38(5-6): 829-848.

Olding, R., Munro, K., Howden, S. and McClymont, K. (2011) 'Man Beaten in Club as Security Diverted Help, Police Claim', Sydney Morning Herald, 31 August 2011, p. 3.

O’Malley, N. (2011) 'The Tough Business of Cleaning Up Security', Sydney Morning Herald, 1 October 2011, p. 8.

Page, B.I., Shapiro, R.Y. and Dempsey, G.R. (1987) 'What Moves Public Opinion?'. American Political Science Review, 1: 23-44.

Pedersen, W., Copes, H. and Sandberg, S. (2016). 'Alcohol and Violence in Nightlife and Party Settings: A Qualitative Study'. Drug and Alcohol Review, 35(5): 557-563.

Potter, G.W. and Kappeler, V.E. (2006) Constructing Crime: Perspectives on Making News and Social Problems (2nd Edition). Long Grove: Waveland Press.

Prenzler, T., Sarre, R. and Earle, K. (2008) 'Developments in the Australian Private Security Industry'. Flinders Journal of Law Reform, 8: 403-417.

Presdee, M. (2000) Cultural Criminology and the Carnival of Crime. London, Routledge. Race, K. (2016) 'The Sexuality of the Night: Violence and Transformation'. Current Issues in Criminal Justice, 28(1): 105-110.

Reich, M., Gordon, D. and Edwards, R. (1973) 'Dual Labor Markets: A Theory of Labour Market Segmentation'. American Economic Review, 63: 359-365.

Rigakos, G. (2008) Nightclub: Bouncers, Risk, and the Spectacle of Consumption. Canada: McGill-Queen's University Press.

Roberts, M. (2009) 'Planning, Urban Design and the Night-time Economy: Still at the Margins?'. Criminology and Criminal Justice, 9(4): 487-506. 
Roberts, M. and Eldridge, A. (2012) Planning the Night-time City. Oxon: Routledge.

Roberts, M., Turner, C., Greenfield, S. and Osborn, G. (2006) 'A Continental Ambience? Lessons in Managing Alcohol-related Evening and Night-time Entertainment from Four European Capitals'. Urban Studies, 43(7): 1105-1125.

Rogers, C. (2016). Plural Policing: Theory and Practice. Bristol: Policy Press.

Rowe, D., Stevenson, D., Tomsen, S., Bavinton, N. and Brass, K. (2008) 'The City After Dark: Cultural Planning and Governance of the Night-time Economy in Parramatta'. Parramatta: Centre for Cultural Research, University of Western Sydney.

Schwarz, M. (2006). One Split Second: The Death of David Hookes and the Trial of Zdravko Micevic. Sydney: University of NSW Press.

Shearing, C. and Stenning, P. (1983) 'Private Security: Implication for Social Control'. Social Problems, 30(5): 493-506.

Shepherd, J., and Brickley, M. (1996) 'The Relationship Between Alcohol Intoxication, Stressors and Injury in Urban Violence', British Journal of Criminology, 36(4): 546-566.

Talbot, D. (2016) Regulating the Night: Race, Culture and Exclusion in the Making of the Night-time Economy. Oxon: Routledge.

Tatlow, J.R., Clapp, J.D. and Hohman, M.M. (2000) 'The Relationship between the Geographic Density of Alcohol Outlets and Alcohol-related Hospital Admissions in San Diego County'. Journal of Community Health, 25: 79-88.

Tierney, J. (2006) 'We Want to be More European: The 2003 Licensing Act and Britain's Night-time Economy'. Social Policy and Society, 5(4): 453-460.

Tomsen, S. (1997) 'A Top Night: Social Protest, Masculinity and the Culture of Drinking Violence'. British Journal of Criminology, 37(1): 90-102.

Tomsen, S. (2005) 'Boozers and Bouncers: Masculine Conflict, Disengagement and the Contemporary Governance of Drinking-related Violence and Disorder'. Australian and New Zealand Journal of Criminology, 38(3): 283-297.

Tomsen, S. (2014a) 'A Dangerous Proximity: The Night-time Economy and the City's Early Morning'. Lo Squaderno: Explorations in Space and Society, 32: 36-40.

Tomsen, S. (2014b) 'Identity Wars: Crime, Safety and Conflict in Sydney's Nighttime Economy'. Etnografia e ricerca qualitativa, 7(3): 463-480.

Tomsen, S. (2018) 'Homicides with Direct and Indirect Links to the Night-time Economy'. Drug and Alcohol Review, 37(6): 794-801.

Tomsen, S. and Wadds, P. (2016) 'Nightlife Ethnography, Violence, Policing and Security', in J. Stubbs and S. Tomsen, Australian Violence: Crime, Criminal Justice and Beyond. Annandale, Australia: Federation Press.

Van Liempt, I. and van Aalst, I. (2012) 'Urban Surveillance and the Struggle between Safe and Exciting Nightlife Districts'. Surveillance \& Society, 9(3): 280-292.

Wadds P. (2011) 'Securing Nightlife: Media Representations of Public and Private Policing', presented at The Australian and New Zealand Critical Criminology Conference 2010, Sydney Law School, Sydney University Law School, Sydney, 1 July 2010-2 July 2010, https://ses.library.usyd.edu.au/bitstream/2123/7374/1/ Wadds_ANZCCC2010.pdf

Wadds, P. (2015) 'Crime, Policing and (In)Security: Press Depictions of Sydney's Night-Time Economy'. Current Issues in Criminal Justice, 27: 95-112. 
Wadds, P. (2019) “ "It's Not Like it Used to Be": Respect and nostalgia in the policing of nightlife'. Australian \& New Zealand Journal of Criminology, 52(2): 213-230.

Wakefield, A. (2012) Selling Security: The Private Policing of Public Space. Devon: Willan Publishing.

Wallace, N. (2004) 'Man in Coma after Nightclub Brawl', Sydney Morning Herald, 22 March 2004, p. 4.

Wells, S. and Graham, K. (2003). 'Aggression Involving Alcohol: Relationship to Drinking Patterns and Social Context'. Addiction, 98(1): 33-42.

Winlow, S. and Hall, S. (2006) Violent Night: Urban Leisure and Contemporary Culture. Oxford: Berg.

Wolifson, P. and Drozdzewski, D. (2017) 'Co-opting the Night: The Entrepreneurial Shift and Economic Imperative in NTE Planning'. Urban Policy and Research, 35(4): 486-504.

Zukin, S. (1991) Landscapes of Power: From Detroit to Disneyland. California: University of California Press.

Zukin, S. (1995) The Cultures of Cities. Oxford: Blackwell. 
alcohol-related industries and economies generated for the Australian states in a time of economic decline from manufacturing and heavy industry. Market deregulation and a liberalisation of alcohol-related policy was touted as a solution to the problems of disreputable leisure practices, as it was believed that increased options for nightlife recreation and leisure would allow for nightlife patrons to enjoy themselves, and thus drink in a more civilised manner in line with Eurocentric ideals of cosmopolitanism (Graham and Homel 2008).

Still more opportunities for drinking were provided by the Greiner government, which gained office in 1988. Nicholas Greiner was the first NSW premier to fully embrace neoliberalism and was thoroughly immersed in freemarket ideology and ideas about reduced public regulation of economic life. A year after its election, the Greiner government secured passage of the Liquor (Amendment) Act 1989 (Wilkinson 1997), which permitted hotels and bottle shops to trade between $5 \mathrm{am}$ and midnight, Monday to Saturday and between $10 \mathrm{am}$ and $10 \mathrm{pm}$ on Sundays. Furthermore, applications could also be made by larger 'entertainment-orientated' hotels to trade until $3 \mathrm{am}$ or, if located in "tourist" areas, until 5 am (Maher, Flaherty and Saunders 1994). This new legislation marked the beginning of what later became known as the late NTE in Sydney.

Towards the end of the 20th century, economic changes were also made at a national level that bore significance to Sydney nightlife. Under the direction of Prime Minister John Howard, the Liberal government strongly pursued neoliberal policies promoting market competition. The National Competition Policy (NCP) had a particularly noteworthy effect on leisure markets in the way that it further naturalised the view that public regulation of alcohol restricted the economic potential of nightlife industries. Under Howard's leadership, the concept of alcohol as an 'ordinary commodity' was officially stated in the NCP (Chikritzhs 2009). These changes preceded significant growth in numbers of licensed premises throughout NSW and the entire country. They also coincided with the emergence of the NTE concept, a detailed examination of which will be undertaken in Chapter 4.

\section{References}

Anderson, B. (1983) Imagined Communities: Reflections on the Origin and Spread of Nationalism. London: Verso.

Australian Bureau of Statistics (ABS) (2011) 'Apparent Consumption of Alcohol: Extended Time Series, 1944-45 to 2008-09'. Canberra: Australian Government Publishing Service.

Bailey, L. and Griffin, C. (2017) 'Social Locations: Class, Gender and Young People's Alcohol Consumption in a Digital World', in A. Lyons, T. McCreanor, I. Goodwin and H. Moewaka Barnes, Youth Drinking Cultures in a Digital World. London: Routledge, pp. 31-48. 
Birmingham, J. (2000) Leviathan: The Unauthorised Biography of Sydney. North Sydney: Random House Australia.

Butlin, N. (1994) Forming a Colonial Economy: Australia 1810-1850. Melbourne: Cambridge University Press.

Caldwell, G.T. (1972) 'The History of Drinking Attitudes in NSW (1900-1945) and the Growth of Registered Clubs'. ANU Historical Journal, (9): 24-31.

Campbell, W.S. (1933) 'The Use and Abuse of Stimulants in the Early Days of Settlement in New South Wales'. Journal and Proceedings of the Royal Australian Historical Society, XVIII: 74-99.

Chikritzhs, T. (2009) 'Chapter 18: Australia', in P. Hadfield (ed.), Nightlife and Crime: Social Order and Governance in International Perspective. Oxford: Oxford University Press.

Conway, R. (1971) The Great Australian Stupor: An Interpretation of the Australian Way of Life. South Melbourne: Sun Books.

Dillon, G. (1985) A Delusion of the Australian Culture. Sydney: NSW Temperance Alliance.

Dingle, A.E. (1980) “"The Truly Magnificent Thirst”: An Historical Survey of Australian Drinking Habits'. Australian Historical Studies, 19(75): 227-249.

Dowling, N., Smith, D. and Thomas, T. (2005) 'Electronic Gaming Machines: Are They the "Crack-cocaine" of Gambling?'. Addiction, 100(1): 33-45.

Emsley, C. (1987) Crime and Society in England, 1750-1900. London: Longman.

Evatt, H.V. (1965) Rum Rebellion: A Study of the Overthrow of Governor Bligh by John Macarthur and the NSW Corps. Sydney: Angus and Robertson.

Faro, C. and Wotherspoon, G. (2000) Street Seen: A History of Oxford Street. Carlton South: Melbourne University Press.

Fileborn, B., Wadds, P. and Barnes, A. (2019) 'Setting the Stage for Sexual Assault: The Dynamics of Gender, Culture, Space and Sexual Violence at Live Music Events', in S. Raine and C. Strong (eds), Towards Gender Equality in the Music Industry Education, Practice and Strategies for Change. London: Bloomsbury Academic, pp. 89-102.

Fileborn, B., Wadds, P. and Tomsen, S. (2019) 'Safety and Sexual Violence at Australian Music Festivals: Final Report'. Available online at: http://dx.doi.org/10.13140/RG.2.2. 30091.85280

Fitzgerald, R. and Jordan, T.L. (2009) Under the Influence: A History of Alcohol in Australia. Sydney: Harper-Collins Publishers.

Freeland, J.M. (1966) The Australian Pub. Melbourne: Melbourne University Press.

Girling-Butcher, T. (2010) Sin City: Crime and Corruption in 20th Century Sydney. Sydney: Historic Houses Trust.

Grabosky, P.N. (1977) Sydney in Ferment: Crime, Dissent and Official Reaction 1788 to 1973. Canberra: Australian National University Press.

Graham K. and Homel, R. (2008) Raising the Bar: Preventing Aggression in and Around Bars, Pubs and Clubs. Devon: Willan Publishing.

Harris, A.T. (2004) Policing the City: Crime and Legal Authority in London, 1780-1840. Columbus: Ohio State University Press.

Hickie, D. (1985) The Prince and the Premier. North Ryde: Angus and Robertson Publishers. 
Hing, N. and Breen, H. (2002) 'A Profile of Gaming Machine Players in Clubs in Sydney, Australia'. Journal of Gambling Studies, 18(2): 185-205.

Hobbs, D., Lister, S., Hadfield, P., Winlow, S. and Hall, S. (2000) 'Receiving Shadows: Governance and Liminality in the Night-time Economy'. British Journal of Sociology, 51(4): 701-717.

Jayne, M., Holloway, S.L. and Valentine, G. (2006) 'Drunk and Disorderly: Alcohol, Urban Life and Public Space'. Progress in Human Geography, 30(4): 451-468.

Jayne, M., Valentine, G. and Holloway, S.L. (2008) 'Fluid Boundaries - British Binge Drinking and European Civility: Alcohol and the Production and Consumption of Public Space'. Space and Polity, 12(1): 81-100.

Keesing, N. (1982) Lily on the Dustbin: Slang of Australian Women and Families. Ringwood: Penguin.

Kerr, C. (2008) 'Alcopop Tax Jacks Up Sales of Spirits'. The Australian, 28 July, p. 5.

Kirkby, D. (2005) “"Maxwell's Silver Hammer ...”: Licensing Laws, Liquor Trading and the Maxwell Royal Commission in NSW, 1951-1954'. ANZLH E-Journal: $118-122$.

Kirkby, D. and Luckins, T. (2006) "“Winnies and Pats ... Brighten Our Pubs": Transforming the Gendered Spatial Economy in the Australian Pub, 1920-1970'. Journal of Australian Studies, 30(87): 75-86.

Larkin, J. (1980) Victorian Country Pubs. Adelaide: Rigby.

Lemmings, D. and Walker, C. (2009) Moral Panics, the Media and the Law in Early Modern England. New York: Palgrave Macmillan.

Lewis, M. (1992) A Rum State: Alcohol and State Policy in Australia. Canberra: Australian Government Publishing Service.

Livingstone, C. and Woolley, R. (2007) 'Risky Business: A Few Provocations on the Regulation of Electronic Gaming Machines'. International Gambling Studies, 7(3): 361-376.

Longmate, N. (1968) The Waterdrinkers: A History of Temperance. London: Hamilton Hamish.

Luckins, T. (2007) 'Pigs, Hogs and Aussie Blokes: The Emergence of the Terms "Six o'clock Swill", History Australia, 4(1): 8.1-8.17.

Luckins, T. (2008) “"Satan Finds Some Mischief?": Drinkers' Responses to the Six o'clock Closing of Pubs in Australia, 1910s-1930s'. Journal of Australian Studies, 32(3): 295-307.

Maher, L., Flaherty, B. and Saunders, J. (1994). 'Flexible Trading Hours for Hotels and Bottleshops in NSW'. Sydney: Drug and Alcohol Directorate, NSW Health Department.

Measham, F. and Brain, K. (2005) " "Binge” Drinking, British Alcohol Policy and the New Culture of Intoxication'. Crime, Media, Culture, 1(3): 262-283.

Midford, R. (2005) 'Australia and Alcohol: Living Down the Legend'. Addiction, 100: 891-896.

New South Wales Government (2019) NSW Budget Statement 2019-20. Accessed online at: www.budget.nsw.gov.au/sites/default/files/budget-2019-06/2019-20\%20 Budget $\% 20$ Paper\%20No.\%201\%20-\%20Budget $\% 20$ Statement $\% 20 \% 281 \% 29$.pdf

Nicholls, J. (2003) 'Gin Lane Revisited: Intoxication and Society in the Gin Epidemic’. Journal for Cultural Research, 7(2): 125-146. 
Phillips, W. (1980) “"Six O'Clock Swill”: The Introduction of Early Closing of Hotel Bars in Australia'. Australian Historical Studies, 19(75): 250-266.

Plant, M. (1991) 'The Age of the Lager Lout?'. Project Annual Report. Glasgow, United Kingdom.

Porter, R. (1990) English Society in the Eighteenth Century. London: Penguin Books.

Powell, K.C. (1988) 'Alcohol and the Eastern Colonies 1788-1901'. Australian Drug and Alcohol Review, 7: 403-411.

Reynolds, E.A. (1998) Before the Bobbies: The Night Watch and Police Reform in Metropolitan London, 1720-1830. Houndmills Basingstoke: Macmillan.

Room, R. (1988) 'The Dialectic of Drinking in Australian Life: From the Rum Corps to the Wine Column'. Australian Drug and Alcohol Review, 7: 413-437.

Room, R. (2010) 'The Long Reaction Against the Wowser: The Prehistory of Alcohol Deregulation in Australia'. Health Sociology Review, 19(2): 151-163.

Sargent, M. (1979) Drinking and Alcoholism in Australia: A Power Relations Theory. Melbourne: Longman Cheshire.

Scott, E. (1941) Australia During the War (8th Edition). Sydney: Angus and Robertson.

Skinner, E. (2007) 'The Gin Craze: Drink, Crime and Women in 18th Century London'. Cultural Shifts, 30 November.

Sturma, M. (1983) Vice in a Vicious Society: Crime and Convicts in Mid-Nineteenth Century NSW. St Lucia: University of Queensland Press.

Trollope, A. (1876) 'Australia and New Zealand', in R. Ward (1974) The Australian Legend. Melbourne: Oxford University Press.

Ward, R. (1974) The Australian Legend. Melbourne: Oxford University Press.

Warner, J., Her, M., Gmel, G. and Rehm, J. (2001) 'Can Legislation Prevent Debauchery? Mother Gin and Public Health in 18th-Century England'. American Journal of Public Health, 91(3): 375-384.

White, J. (2003) 'The "Slow but Sure Poyson": The Representation of Gin and Its Drinkers, 1736-1751'. The Journal of British Studies, 42(1): 35-64.

Wilkinson, J. (1997) 'Alcohol and Tobacco in NSW: Consumption, Revenue and Concern', Briefing Paper no. 7. NSW Parliament Library Research Service.

Writer, L. (2001) Razor: A True Story of Slashers, Gangsters, Prostitutes and Sly Grog. Sydney: Pan Macmillan.

Yeomans, H. (2011) 'What Did the British Temperance Movement Accomplish? Attitudes to Alcohol, the Law and Moral Regulation'. Sociology, 45(1): 38-53.

Yeomans, H. (2019) 'Regulating Drinking Through Alcohol Taxation and Minimum Unit Pricing: A Historical Perspective on Alcohol Pricing Interventions'. Regulation \& Governance, 13(1): 3-17.

Young, M., Markham, F. and Doran, B. (2012) 'Placing Bets: Gambling Venues and the Distribution of Harm'. Australian Geographer, 43(4): 425-444. 
size between these two occupational segments is likely much larger. Such figures provide evidence to the re-constitution of policing in post-industrial society. In the search to provide increasingly anxious national populations with a more visible security presence, it seems that the private security industry is filling the gap where the largely restricted public sector is falling short. Consequently, "it is now almost impossible to identify any function or responsibility of the public police which is not, somewhere and under some circumstances, assumed and performed by private police in democratic societies" (Stenning 2000: 328).

Prenzler, Sarre and Earle (2008) also noted the dramatic increase in market demand for private security, insurance requirements, the increased liability and legal responsibilities placed on property owners for visitors and staff and improvements in security technology as catalysts for the rapid expansion of the private security industry. One of the most visible sites of this transformation, and the dual pursuit of further use of private security and situational crime prevention measures, is the NTE. While public policing in the NTE is present, the policing agenda favours intermittent and targeted strategies, leaving the private sector to provide the more constant vigil. The success of this approach is frequently lauded in the media, although its actual impact on addressing public needs is questionable. The resources required for operations beyond these high-visibility public policing blitzes are said to be beyond the capacity of the police to provide on a regular basis. Even as rates of assault and other offences relating to night-time leisure have fluctuated with different policies and policing practices, fear and insecurity are still widespread. The role of the police in relation to this community anxiety must, therefore, be further analysed, along with other factors impinging on the contemporary policing of public order and drinking in Sydney, such as the rapid expansion of the private security industry and the mixed gentrification of urban nightlife precincts.

\section{References}

Bayley, D.H. and Shearing, C.D. (1996) 'The Future of Policing'. Law and Society Review, 30(3): 585-606.

Beck, U. (1992) Risk Society: Towards and New Modernity. London: Sage.

Birmingham, J. (2000) Leviathan: The Unauthorised Biography of Sydney. North Sydney: Random House Australia.

Bittner, E. (1990) 'Some Reflections on Staffing Problem-orientated Policing'. American Journal of Police, 9: 189-191.

Bradley, D. (1996) 'Contemporary police education in Australia', in D. Chappell and P. Wilson (eds) Australian Policing: Contemporary Issues. Sydney: Butterworths.

Bradley, T. (2017) 'The Pluralisation of Policing', in A. Deckert and R. Sarre (eds), The Palgrave Handbook of Australian and New Zealand Criminology, Crime and Justice. Cham: Palgrave Macmillan, pp. 497-510. 
Brough, P., Chataway, S. and Biggs, A. (2016). “"You Don't Want People Knowing You're a Copper!” A Contemporary Assessment of Police Organisational Culture'. International Journal of Police Science \& Management, 18(1): 28-36.

Brown, L.P. (1974) 'The Police and Higher Education: The Challenge of the Times'. Criminology, 12: 114-124.

Button, M. (2002) Private Policing. Devon: Willan Publishing.

Carter, D. and Sapp, A. (1990) 'The Evolution of Higher Education in Law Enforcement: Preliminary Findings from a National Study'. Journal of Criminal Justice Education, 1(1): 59-61.

Chan, J. (1997) Changing Police Culture: Policing in a Multicultural Society. New York: Cambridge University Press.

Chan, J. (1999) 'Police Culture', in D. Dixon (ed.), A Culture of Corruption: Changing an Australian Police Service. Sydney: Hawkins Press.

Chan, J. (2003) 'Governing Police Practice: Limits of the New Accountability'. The British Journal of Sociology, 50: 251-270.

Crawford, A., Lister, S., Blackburn, S. and Burnett, J. (2005) Plural Policing: The Mixed Economy of Visible Patrols in England and Wales. Bristol: Policy Press.

Cockburn, M. and Steketee, M. (1986) Wran: An Unauthorised Biography. Sydney: Allen and Unwin.

Davis, J. (1991) 'Urban Policing and It's Objects: Comparative Themes in England and France in the Second Half of the Nineteenth Century', in C. Emsley and B. Weinberger (eds), Policing Western Europe: Politics, Professionalism and Public Order, 1850-1940. Westport: Greenwood Publishing.

Dixon, D. (1999) A Culture of Corruption: Changing an Australian Police Service. Sydney: Hawkins Press.

Eck, J.E. (2019) 'Why Problem Oriented Policing', in D. Weisburd and A.A. Braga (eds), Police Innovations: Contrasting Perspectives. Cambridge: Cambridge University Press.

Eick, V. and Briken, K. (2014) Urban (In) Security: Policing the Neoliberal Crisis. Ottawa: Red Quill Books.

Eck, J.E. and Spelman, W. (1987) 'Who Ya Gonna Call? The Police as Problembusters'. Crime \& Delinquency, 33(1): 31-52.

Emsley, C. (1987) Crime and Society in England, 1750-1900. London: Longman.

Ericson, R.V. (2007) Crime in an Insecure World. Cambridge: Polity Press.

Evatt, H.V. (1965) Rum Rebellion: A Study of the Overthrow of Governor Bligh by John Macarthur and the NSW Corps. Sydney: Angus and Robertson.

Fileborn, B., Wadds, P. and Barnes, A. (2019) 'Setting the Stage for Sexual Assault: The Dynamics of Gender, Culture, Space and Sexual Violence at Live Music Events', in S. Raine and C. Strong (eds), Towards Gender Equality in the Music Industry Education, Practice and Strategies for Change. London: Bloomsbury Academic, pp. 89-102.

Fileborn, B., Wadds, P. and Tomsen, S. (2019) 'Safety and Sexual Violence at Australian Music Festivals: Final Report'. Available online at: http://dx.doi.org/10.13140/ RG.2.2.30091.85280

Finnane, M. (1987) Policing in Australia: Historical Perspectives. Kensington: UNSW Press. 
Finnane, M. (1995) 'From Police Force to Police Service? Aspects of the Recent History of the NSW Police'. Paper prepared for the Royal Commission into the NSW Police Service.

Finnane, M. (1996) Police and Government: Histories of Policing in Australia. Melbourne: Oxford University Press.

Finnane, M. (2008) 'Law and Order'. Dictionary of Sydney. Viewed 29 March, 2012. Access online at: www.dictionaryofsydney.org/entry/law_and_order

Fitzgerald, R. and Jordan, T.L. (2009) Under the Influence: A History of Alcohol in Australia. Sydney: Harper-Collins Publishers.

Fleming, J. (2008) Rules of Engagement: Policing Anti-Social Behaviour and AlcoholRelated Violence in and Around Licensed Premises. Sydney: NSW Bureau of Crime Statistics and Research.

Garland, D. (1996) 'The Limits of the Sovereign State: Strategies of Crime Control in Contemporary Society'. British Journal of Criminology, 36(4): 445-471.

Garland, D. (2001) The Culture of Control: Crime and Social Order in Contemporary Society. Oxford: Clarendon.

Girling-Butcher, T. (2010) Sin City: Crime and Corruption in 20th Century Sydney. Sydney: Historic Houses Trust.

Godfrey, B.S., Williams, C.A. and Lawrence, P. (2008) History and Crime. London: Sage.

Goldstein, H. (1979) 'Improving Policing: A Problem-oriented Approach'. Crime \& Delinquency, 25(2): 236-258.

Gordon, T. (2005) 'The Political Economy of Law-and-order Policies: Policing, Class Struggle, and Neoliberal Restructuring'. Studies in Political Economy, 75(1): 53-77.

Gouldstein, H. (1977) Policing a Free Society. Cambridge: Ballinger Publishing Company.

Grabosky, P.N. (1977) Sydney in Ferment: Crime, Dissent and Official Reaction 1788 to 1973. Canberra: Australian National University Press.

Grewcock, M. and Sentas, V. (2019) 'Rethinking Strip Searches by NSW Police: Final Report'. Sydney: The University of New South Wales.

Harvey, D. (2007) A Brief History of Neoliberalism. Oxford: Oxford University Press.

Hickie, D. (1985) The Prince and the Premier. North Ryde: Angus and Robertson Publishers.

Hogg, R. and Brown, D. (1998) Rethinking Law and Order. Annandale: Pluto Press.

Hogg, R. and Golder, H. (1987) 'Policing Sydney in the Late Nineteenth Century', in M. Finnane (ed.), Policing in Australia: Historical Perspectives. Kensington: UNSW Press. Hubbard, P. (2003) 'Fear and Loathing at the Multiplex: Everyday Anxiety in the Post-industrial City'. Capital and Class, 27(2): 51-75.

Hughes, C.E., Moxham-Hall, V., Ritter, A., Weatherburn, D. and MacCoun, R. (2017) 'The Deterrent Effects of Australian Street-level Drug Law Enforcement on Illicit Drug Offending at Outdoor Music Festivals'. International Journal of Drug Policy, 41: 91-100.

Hughes, E.C. (1962) 'Good People and Dirty Work'. Social Problems, Vol. X.

Ignatieff, M. (1979) 'Police and People: The Birth of Mr. Peel's Blue Locusts'. New Society, 49(882): 443-445. 
James, S. and Warren, I. (1995) 'Police Culture', in J. Bessant, K. Carrington and S. Cook (eds), Cultures of Crime and Violence: The Australian Experience. Bundoora: La Trobe University Press.

Johnston, L. (1992) The Rebirth of Private Policing. London: Routledge.

Jones, T.T. and Newburn, T. (2002) 'The Transformation of Policing? Understanding

Current Trends in Policing Systems'. British Journal of Criminology, 42(1): 129-146.

Karskens, G. and Waterhouse, R. (2010) “"Too Sacred to Be Taken Away”: Property, Liberty, Tyranny and the "Rum Rebellion"'. Journal of Australian Colonial History, 12(1): 1-22.

Lee, M. (2007) Inventing Fear of Crime: Criminology and the Politics of Anxiety. Devon: Willan Publishing.

Lee, M. and Punch, M. (2004) 'Policing by Degrees: Police Officers' Experience of University Education'. Policing and Society, 14(3): 233-249.

Lewis, M. (1992) A Rum State: Alcohol and State Policy in Australia. Canberra: Australian Government Publishing Service.

Loader, I. (2000) 'Plural Policing and Democratic Governance'. Social E Legal Studies, 9(3): 323-345.

Loader, I. and Sparks, R. (2002) 'Contemporary Landscapes of Crime, Order and Control: Governance, Risk, and Globalization', in M. Maguire, R. Morgan and R. Reiner (eds.), The Oxford Handbook of Criminology: Third Edition. Oxford: Oxford University Press, pp. 83-112.

Lusher Report (1981) Report of the Commission of Inquiry into NSW Police Administration. Sydney: NSW Government Printer.

Maguire, M. (2012) 'Criminal Statistics and the Construction of Crime', in R. Morgan, M. Maguire and R. Reiner (eds), The Oxford Handbook of Criminology (5th Edition). Oxford: Oxford University Press, pp. 206-244.

McCoy, A. (1980) Drug Traffic: Narcotics and Organised Crime in Australia. Sydney: Harper and Row.

McCulloch, J. (2001) Blue Army: Paramilitary Policing in Australia. Melbourne: Melbourne University Press.

Newburn, T. (2001) 'The Commodification of Policing: Security Networks in the Late Modern City'. Urban Studies, 38(5-6): 829-848.

O'Malley, P. (1983) Law, Capitalism and Democracy: A Sociology of Australian Legal Order. Sydney: Allen and Unwin.

O'Malley, P. (1992) 'Risk, Power and Crime Prevention'. Economy and Society, 21(3): 252-275.

Pasquino, P. (1991) 'Theatrum Politicum: The Genealogy of Capital-police and the State of Prosperity', in G. Burchell, C. Gordon and P. Miller (eds), The Foucault Effect: Studies in Governmentality. Chicago: University of Chicago Press, pp. 105-118.

Prenzler, T. and Sarre, R. (2002) 'The Policing Complex', in A. Graycar and P. Grabosky (eds), The Cambridge Handbook of Australian Criminology. Cambridge: Cambridge University Press.

Prenzler, T., Sarre, R. and Earle, K. (2008) 'Developments in the Australian Private Security Industry'. Flinders Journal of Law Reform, 8: 403-417.

Rawlings, P. (2002) Policing: A Short History. Devon: Willan Publishing.

Reiner, R. (2000) The Politics of the Police. Oxford: Oxford University Press. 
Reiner, R. (2007). Law and Order: An Honest Citizen's Guide to Crime and Control. Cambridge: Polity Press.

Reiner, R., Livingstone, S. and Allen, J. (2000) 'No More Happy Endings? The Media and Popular Concern about Crime Since the Second World War', in T. Hope and R. Sparks (eds), Crime, Risk and Insecurity: Law and Order in Everyday Life and Political Discourse. London, Routledge, pp. 107-126.

Report of the Royal Commission on Liquor Laws in NSW (1954) Sydney: NSW Government Printer.

Resolutions (1990) '18th Meeting of the Australian Police Ministers' Council (8/03/1990)', cited in H. Winzler (2006) Professionalisation of Policing in Australasia and the Evolution of the Australian Police Professional Standards Council - A Short History. Melbourne.

Reynolds, E.A. (1998) Before the Bobbies: The Night Watch and Police Reform in Metropolitan London, 1720-1830. Houndmills, Basingstoke: Macmillan.

Rock, P. (1977) 'Law, Order and Power in Late Seventeenth and Early Eighteenth Century England'. International Annals of Criminology, 16: 233-265.

Rogers, C. (2016). Plural Policing: Theory and Practice. Bristol: Policy Press.

Rose, N. (1996) 'The Death of the Social? Re-figuring the Territory of Government'. Economy and Society, 25(3): 327-356.

Silver, A. (1965) 'On Demand for Order in Civil Society: A Review of Some Themes in the History of Urban Crime, Police and Riot in England'. Paper No. 11, Working Papers for the Centre for Research on Social Organisation, Department of Sociology, University of Michigan. Available online at: https://deepblue.lib.umich. edu/bitstream/handle/2027.42/50796/11.pdf?sequence=1\&isAllowed=y

Skogan, W.G. (1981) Issues in the Measurement of Victimization. US Department of Justice, Bureau of Justice Statistics, 70(11).

Sparks, R., Girling, E. and Loader, I. (2001) 'Fear and Everyday Urban Lives'. Urban Studies, 38(5-6): 885-898.

Stenning, P. (2000) 'Powers and Accountability of Private Police'. European Journal of Criminal Policy and Research, 8 (3): 325-352.

Stenson, K. (2001) 'Reconstructing the Government of Crime', in G. Pavlich (ed.). Rethinking Law, Society and Governance: Foucault's Bequest. Oxford: Hart Publishing, pp. 93-108.

Storch, R. (1975) 'The Plague of Blue Locusts: Police Reform and Popular Resistance in Northern England 1800-57', International Review of Social History, 20: 61-90.

Sturma, M. (1983) Vice in a Vicious Society: Crime and Convicts in Mid-Nineteenth Century NSW. St Lucia: University of Queensland Press.

Sturma, M. (1987) 'Policing the Criminal Frontier in Mid-Nineteenth Century Australia, Britain and America', in M. Finnane (ed.), Policing in Australia: Historical Perspectives. Kensington: UNSW Press.

Swanton, B. and Hoban, L. (1990) 'Frederick John Hanson, CBE, QPM, 11th Commissioner of the NSW Police'. NSW Police News, 70 (12): 29-33. Cited in D. Dixon (ed.) (1999) A Culture of Corruption: Changing an Australian Police Service. Annandale: Hawkins Press.

Walklate, S. (2011) 'Reframing Criminal Victimization: Finding a Place for Vulnerability and Resilience'. Theoretical Criminology, 15(2): 179-194. 
Weatherburn, D. and Indermaur, D. (2004) 'Public Perceptions of Crime Trends in New South Wales and Western Australia'. BOCSAR NSW Crime and Justice Bulletin no. 8.

Whitehead, A. (1967) The Aims of Education and Other Essays. New York: Free Press.

Wimhurst, K. and Ransley, J. (2007) 'Police Education and the University Sector: Contrasting Models from the Australian Experience'. Journal of Criminal Justice Education, 18(1): 106-122.

Wood, J. (1997a) Royal Commission into the NSW Police Service, Final Report, Volume I: Corruption. Sydney: Government Printer.

Wood, J. (1997b) Royal Commission into the NSW Police Service, Final Report, Volume II: Reform. Sydney: NSW Government Printer.

Writer, L. (2001) Razor: A True Story of Slashers, Gangsters, Prostitutes and Sly Grog. Sydney: Pan Macmillan.

Yeomans, H. (2011) 'What Did the British Temperance Movement Accomplish? Attitudes to Alcohol, the Law and Moral Regulation'. Sociology, 45(1): 38-53.

Yeomans, H. (2014) Alcohol and Moral Regulation: Public Attitudes, Spirited Measures and Victorian Hangovers. Bristol: Policy Press.

Zedner, L. (2006) 'Policing Before and After the Police: The Historical Antecedents of Contemporary Crime Control'. British Journal of Criminology, 46: 78-96. 
to which potential employees are subject before being granted a security license. These processes were put in place to attempt to limit the number of persons with recorded histories of violence from working in the industry. Alongside the increase in probity checks, more substantial training programs have been introduced to ensure that prospective workers have a more complete understanding of the demands, and limitations, of their roles. A probation period of one year has also been introduced to ensure that those with no experience in the industry are subjected to more rigorous 'on-the-job' supervision by experienced staff. However, training in physical intervention techniques are still not part of this training. This omission is a major flaw in current industry requirements that must be addressed if any attempts to 'professionalise' the industry are to be taken seriously.

While the security industry still battles with its negative image, the new regulations introduced under the NSW Security Industry Regulation Act, $2007 / 2016$ ostensibly restrict 'cowboys' from entering the occupation. The upgraded requirements of training and probity undoubtedly represent a significant and positive progression, but the low base of regulation from which the industry started means that there is clearly still a long way to go. Without clearly defined powers, backed up by appropriate levels of training, the industry cannot effectively undertake its expanded duties and will continue to be plagued by civil claims against operators who have exceeded vaguely defined workplace standards.

\section{References}

Amin, A. (ed.) (1995) Post-Fordism: A Reader. Oxford: Blackwell.

Amin, A. and Malmberg, A. (1995) 'Competing Structural and Institutional Influences on the Geography of Production in Europe', in A. Amin (ed.), Post-Fordism: A Reader. Oxford: Blackwell.

Avery, J. (1981) Police- Force or Service? Sydney: Butterworths.

Bevan, T., Turnham, A., Lester, M. and Hadfield, P. (2011) 'Sydney Night Time Economy: A Cost Benefit Analysis'. Sydney, City of Sydney Council. Available online at: www.cityofsydney.nsw.gov.au/_data/assets/pdf_file/0006/131739/Night TimeEconomyCostBenefitAnalysisReport.pdf

Bianchini, F. (1995) 'Night Cultures, Night Economies'. Planning Practice and Research, 10(2): 121-126.

BOCSAR (2019) 'Alcohol-related Violence'. Available online at: www.bocsar.nsw.gov. au/Pages/bocsar_pages/Alcohol_Related_Violence.aspx. Accessed 20 October 2019.

Branley, A. (2016) 'Leaked Documents Show Star Casino Under-reporting Violence'. PM with Mark Colvin, ABC Radio, 31 October. Accessed online at: www. abc.net.au/pm/content/2016/s4566342.htm

Buerger, M.E. and Mazerolle, L.G. (1998) 'Third-party Policing: A Theoretical Analysis of an Emerging Trend'. Justice Quarterly, 15(2): 301-327.

Cavan, S. (1966) Liquor License. Chicago: Aldine Publishing Company. 
Chan, J. (1997) Changing Police Culture: Policing in a Multicultural Society. New York: Cambridge University Press.

Chatterton, P. and Hollands, R. (2002) 'Theorising Urban Playscapes: Producing, Regulating and Consuming Youthful Nightlife City Spaces'. Urban Studies, 39(1): 95-116.

Chikritzhs, T. and Stockwell, T. (2002) 'The Impact of Later Trading Hour for Australian Public Houses (Hotels) on Levels of Violence'. Journal of Studies on Alcohol, 63: 591-599.

Chikritzhs, T. (2009) 'Australia', in P. Hadfield (ed.), Nightlife and Crime: Social Order and Governance in International Perspective. Oxford: Oxford University Press.

City of Sydney (2008) 'Sustainable Sydney 2030: The Vision'. Sydney: City of Sydney.

City of Sydney (2011) 'Open Late for Everyone: Time to Have Your Say: Night Time Economy Phase Two'. Accessed online at: www.sydneyyoursay.com.au/ nighteconomyphase2

City of Sydney (2012) 'Summary of Online Submissions for OPEN Sydney Discussion Paper'. Accessed online at: meetings.cityofsydney.nsw.gov.au/council/about council/meetings/documents/meetings/2012/Committee/Cultural/180612/ 120618_CCSC_ITEM08_ATTACHMENTC.PDF

City of Sydney (2013) OPEN Sydney, Future Directions for Sydney at Night: Strategy and Action Plan 2013-2030. Sydney: City of Sydney Council.

City of Sydney (2018) An Open and Creative City: Analysis of submissions. Sydney: Global Research Group.

City of Sydney (2019) 'Submission to the Joint Select Committee: Sydney's Nighttime Economy'. Sydney NSW Parliament.

Comedia (1991) Out of Hours: A Study of Economic, Social and Cultural Life in Twelve Town Centres in the UK: Summary Report. London: Comedia and Calouste Gulbenkian Foundation.

Coomber, K., Mayshak, R., Hyder, S., Droste, N., Curtis, A., Pennay, A., Gilmore, W., Lam, T., Chikritzhs, T. and Miller, P., (2017) 'Demographic and Substance Use Factors Associated with Non-violent Alcohol-related Injuries among Patrons of Australian Night-time Entertainment Districts'. International Journal of Environmental Research and Public Health, 14(1): 75-84.

Curtis, A., Miller, P., Droste, N., McFarlane, E., Martino, F. and Palmer, D. (2016) 'The Ones that Turn Up Are the Ones that Are Responsible': Key Stakeholders Perspectives on Liquor Accords. Drug and Alcohol Review, 35(3): 273-279.

Deloitte (2018) Imagine Sydney: Play. Sydney, Deloitte Access Economics.

Devroe, E., Edwards, A. and Ponsaers, P. (2017) 'Processes of Convergence and Divergence in the Policy Formulation of Policing Strategies for European Metropolises', in E. Devroe, A. Edwards and P. Ponsaers (eds), Policing European Metropolises: The Politics of Security in City-regions. Oxon: Routledge, pp. 3-22.

Donnelly, N. and Briscoe, S. (2002) 'Young Adults' Experience of Responsible Service Practice in NSW'. Alcohol Studies Bulletin no. 3, NSW Bureau of Crime Statistics and Research.

Donnelly, N. and Poynton, S. (2019) 'The Effect of Lockout and Last Drinks Laws on Non-domestic Assaults in Sydney: An Update to March 2019 (Bureau Brief No. 142)'. NSW Bureau of Crime Statistics and Research. 
Donnelly, N. and Snowball, L. (2006) 'Recent Trends in Property and Drug-related Crime in Kings Cross'. Contemporary Issues in Crime and Justice: no. 105. NSW Bureau of Crime Statistics and Research.

Donnelly, N., Scott, L., Poynton, S., Weatherburn, D., Shanahan, M. and Hansen, F. (2007) 'Estimating the Short-Term Cost of Police Time Spent Dealing with Alcohol-Related Crime in NSW'. Monograph Series no. 25. Hobart, National Drug Law Enforcement Research Fund.

Doran, C., Wadds, P., Shakeshaft, A. and Tran, D.A. (2020) Evaluation of the Take Kare Safe Space Program: Final Report. Sydney, NSW Department of Justice.

Ennis, G. and Finlayson, M. (2015) 'Alcohol, Violence, and a Fast Growing Male Population: Exploring a Risky-mix in "boomtown" Darwin'. Social Work in Public Health, 30(1): 51-63.

Evershed, N. (2016) 'Sydney's Lockout Laws - Five Key Facts About the City's Alcohol Debate', Guardian, 11 February, 2016. Available online at: www.theguardian.com/ news/datablog/2016/feb/11/sydneys-lockout-laws-five-key-facts-about-the-citysalcohol-debate

Exum, M.L. (2006) 'Alcohol and Aggression: An Integration of Findings from Experimental Studies'. Journal of Criminal Justice, 34(2): 131-145.

Faro, C. and Wotherspoon, G. (2000) Street Seen: A History of Oxford Street. Carlton South: Melbourne University Press.

Featherstone, M. (1991) Consumer Culture and Postmodernism. London: Sage.

Fileborn B. (2016) Reclaiming the Night-time Economy: Unwanted Sexual Attention in Pubs and Clubs. London: Palgrave Macmillan.

Fileborn, B., Wadds, P. and Barnes, A. (2019) 'Setting the Stage for Sexual Assault: The Dynamics of Gender, Culture, Space and Sexual Violence at Live Music Events', in Raine S. and Strong C. (eds), Towards Gender Equality in the Music Industry Education, Practice and Strategies for Change. London: Bloomsbury Academic, pp. 89-102.

Fileborn, B., Wadds, P. and Tomsen, S. (2019) 'Safety and Sexual Violence at Australian Music Festivals: Final Report'. Available online at: http://dx.doi.org/10.13140/RG.2.2. 30091.85280

Fleming, J. (2010) 'Community Policing: the Australian Connection', in J. Putt (ed.), 'Community Policing in Australia'. Research and Public Policy Series no. 111. Canberra: Australian Institute of Criminology.

Fox, A. and MacAvoy, M. (eds) (2011) Expressions of Drunkenness (Four Hundred Rabbits). New York: Routledge.

Goh, D. and Ramsey, S. (2019) 'An Update of Long-term Trends in Property and Violent Crime in New South Wales: 1990-2018'. Bureau Brief No. 139. NSW Bureau of Crime Statistics and Research.

Graham, K. (1985) 'Determinants of Heavy Drinking and Drinking Problems: The Contribution of the Bar Environment', in E. Single and T. Storm (eds), Public Drinking and Public Policy. Toronto: Addiction Research Foundation, pp. 71-84.

Graham, K. (1999) Safer Bars: Assessing and Reducing Risks of Violence. Toronto: Centre for Addiction and Mental Health.

Graham, K. and Homel, R. (1997) 'Creating Safer Bars', in M. Plant, E. Single, and T. Stockwell (eds), Alcohol: Minimizing the Harm. London: Free Association Press, pp. 171-192. 
Graham, K. and Wells, S. (2003) “"Somebody's Gonna Get Their Head Kicked in Tonight!": Aggression Among Young Males in Bars: A Question of Values?'. British Journal of Criminology, 43(3): 546-566.

Graham K. and Homel, R. (2008) Raising the Bar: Preventing Aggression in and Around Bars, Pubs and Clubs. Devon: Willan Publishing.

Graham, K., Bernards, S., Osgood, D.W., Homel, R. and Purcell, J. (2005) 'Guardians and Handlers: The Role of Bar Staff in Preventing and Managing Aggression'. Addiction, 100: 755-766.

Graham, K., Bernards, S., Osgood, D.W. and Wells, S. (2006) 'Bad Nights or Bad Bars? Multi-level Analysis of Environmental Predictors of Aggression in Late Night Large-capacity Bars and Clubs'. Addiction, 101: 1569-1580.

Graham, K., West, P. and Wells, S. (2000) 'Evaluating Theories of Alcohol-related Aggression Using Observations of Young Adults in Bars'. Addiction, 95(6): 847-863.

Hadfield, P. (2006) Bar Wars: Contesting the Night in Contemporary British Cities. Oxford: Oxford University Press.

Hadfield, P., Lister, S., Hobbs, D. and Winlow, S. (2001) 'The "24 Hour City": Condition Critical?'. Town and Country Planning: 300-302.

Hannigan, J. (1998) Fantasy City: Pleasure and Profit in the Postmodern Metropolis. London: Routledge.

Harvey, D. (1989) 'From Managerialism to Entrepreneurialism: The Transformation in Urban Governance in Late Capitalism'. Geografiska Annaler, 71(1): 3-17.

Hayward, K. and Hobbs, D. (2007) 'Beyond the Binge in "Booze Britain": Marketled Liminalization and the Spectacle of Binge Drinking'. British Journal of Sociology, 58(3): 437-456.

Heath, T. (1997) 'The Twenty-four Hour City Concept: A Review of Initiatives in British Cities'. Journal of Urban Design, 2(2): 193-204.

Hobbs, D., Lister, S., Hadfield, P., Winlow, S. and Hall, S. (2000) 'Receiving Shadows: Governance and Liminality in the Night-time Economy'. British Journal of Sociology, 51(4): 701-717.

Hobbs, D., Hadfield, P., Lister, S. and Winlow, S. (2003) Bouncers: Violence and Governance in the Night-time Economy. Oxford: Oxford University Press.

Hollands, R. and Chatterton, P. (2003) 'Producing Nightlife in the New Urban Entertainment Economy: Corporatization, Branding and Market Segmentation'. International Journal of Urban and Regional Research, 27(2): 361-385.

Homan, S. (2019) “"Lockout” Laws or "Rock Out" Laws? Governing Sydney's Night-time Economy and Implications for the "Music City", International Journal of Cultural Policy, 25(4): 500-514.

Homel, R., Tomsen, S. and Thommeny, J. (1992) 'Public Drinking and Violence: Not Just an Alcohol Problem'. Journal of Drug Issues, 22(3): 679-697.

Homel, R. and Tomsen, S. (1993) 'Hot Spots for Violence: The Environment of Pubs and Clubs', in H. Strang and S. Gerull (eds), Homicide: Patterns, Prevention and Control: Proceedings of a Conference Held 12-14 May, 1992. Canberra: Australian Institute of Criminology.

Howden, S. and Ralston, N. (2011) 'Private Army of the Cross', The Sun Herald, 20 March, p. 19. 
Hubbard, P. (2003) 'Fear and Loathing at the Multiplex: Everyday Anxiety in the Post-industrial City'. Capital and Class, 27(2): 51-75.

Hubbard, P. (2013) 'Carnage! Coming to a Town Near You? Nightlife, Uncivilised Behaviour and the Carnivalesque Body'. Leisure Studies, 32(3): 265-282.

Hughes, G. (1999) 'Urban Revitalization: The Use of Festive Time Strategies'. Leisure Studies, 18(2): 119-135.

Hughes, C.E. and Weedon-Newstead, A.S. (2018) 'Investigating Displacement Effects as a Result of the Sydney, NSW Alcohol Lockout Legislation'. Drugs: Education, Prevention and Policy, 25(5): 386-396.

Jayne, M. (2005). Cities and Consumption. Oxon: Routledge.

Jayne, M., Holloway, S.L. and Valentine, G. (2006) 'Drunk and Disorderly: Alcohol, Urban Life and Public Space'. Progress in Human Geography, 30(4): 451-468.

Jayne, M. and Valentine, G. (2016). 'Alcohol-related Violence and Disorder: New Critical Perspectives'. Progress in Human Geography, 40(1): 67-87.

Jones, L., Hughes, K., Atkinson, A.M. and Bellis, M.A. (2011) 'Reducing Harm in Drinking Environments: A Systematic Review of Effective Approaches'. Health \& Place, 17(2): 508-518.

Landry, C., Greene, L., Matarasso, F. and Bianchini, F. (1995) The Art of Regeneration: Urban Renewal Through Cultural Activity. London: Comedia.

Lash, S. and Urry, J. (1987) The End of Organised Capitalism. Cambridge: Polity Press.

Laslett, A.M, Catalano, P., Chikritzhs, T., Dale, C., Doran, C., Ferris, J. and Wilkinson, C. (2010) The Range and Magnitude of Alcohol's Harm to Others. Fitzroy: AER Centre for Alcohol Policy Research, Turning Point Alcohol and Drug Centre, Eastern Health.

Lee, M. (2016) 'Sydney's Lockout Laws: For and Against'. Current Issues in Criminal Justice, 28(1): 117-121.

Lee, M. and Herborn, P. (2003) 'The Role of Place Management in Crime Prevention: Some Reflections on Governmentality and Government Strategies'. Current Issues in Criminal Justice, 15(1): 26-39.

Lee, M., Tomsen, S. and Wadds, P. (2020) 'Locking-out Uncertainty: Conflict and Risk in Sydney's Night-time Economy', in J. Pratt (ed.), Criminal Justice, Risk and the Revolt against Uncertainty. Melbourne: Palgrave Macmillan.

License, A. and Edwards, A. (2019) Measuring the Australian Night Time Economy 2018: A Report Compiled for the Council of Capital City Lord Mayors. Sydney, Ingenium Research.

Lindsay, J. (2012) 'The Gendered Trouble with Alcohol: Young People Managing Alcohol Related Violence'. International Journal of Drug Policy, 23(3): 236-241.

Lipovetsky, G. (1994) The Empire of Fashion: Dressing Modern Democracy. Princeton: Princeton University Press.

Livingstone, C. and Adams, P.J. (2011) 'Harm Promotion: Observations on the Symbiosis between Government and Private Industries in Australasia for the Development of Highly Accessible Gambling Markets'. Addiction, 106(1): 3-8.

Loader, I. (2000) 'Plural Policing and Democratic Governance'. Social E Legal Studies, 9(3): 323-345.

Lofland, L. (1973) A World of Strangers: Order and Action in Urban Public Space. Waveland: Prospect Heights. 
Lovatt, A. and O'Connor, J. (1995) 'Cities and the Night-time Economy', Planning Practice and Research, 10(2): 127-133.

Lovatt, A. (2017). 'The Ecstasy of Urban Regeneration: Regulation of the Night-time Economy in the Transition to a Post-Fordist City', in J. O'Connor and D. Wynne (eds), From the Margins to the Centre: Cultural Production and Consumption in the PostIndustrial City. Oxon: Routledge, pp. 141-168.

MacAndrew, C. and Edgerton, R.B. (1969) Drunken Comportment: A Social Explanation. Chicago: Aldine Publishing Company.

Malbon, B. (1998) 'The Club, Clubbing: Consumption, Identity and the Spatial Practices of Every-Night Life', in T. Shelton and G. Valentine (eds), Cool Places: Geographies of Youth Cultures. London: Routledge.

Mazerolle, L. and Ransley, J. (2005) Third Party Policing. Cambridge: Cambridge University Press.

McNeill, D. (2011) 'Fine Grain, Global City: Jan Gehl, Public Space and Commercial Culture in Central Sydney'. Journal of Urban Design, 16(2): 161-178.

Measham, F. (2004a) 'Play Space: Historical and Socio-cultural Reflections on Drugs, Licensed Leisure Locations, Commercialisation and Control'. International Journal of Drug Policy, 15(5): 337-345.

Measham, F. (2004b) 'The Decline of Ecstasy, the Rise of Binge Drinking and the Persistence of Pleasure'. Probation Journal, 51(4): 309-326.

Measham, F. and Brain, K. (2005) “"Binge” Drinking, British Alcohol Policy and the New Culture of Intoxication'. Crime, Media, Culture, 1(3): 262-283.

Miller, P., Pennay, A., Droste, N., Jenkinson, R., Quinn, B., Chikritzhs, T., Tomsen, S., Wadds, P., Jones, S., Palmer, D., Barrie, L., Lam, T., Gilmore, W. and Lubman, D. (2013) Patron Offending and Intoxication in Night-time Entertainment Districts (POINTED): Final Report. Melbourne: NDLERF.

Moffatt, S., Mason, A., Borzycki, C. and Weatherburn, D. (2009) 'Liquor Licensing Enforcement and Assaults on Licensed Premises'. Bureau Brief No. 40. NSW Bureau of Crime Statistics and Research.

Montgomery, J. (2004) 'Born to Binge? Licensing and the 24-hour City'. Town and Country Planning: 82-83.

Moore, C. (2013) 'Arts \& Culture: A Flourishing Cultural Life Enriches Our City and Community'. Accessed online at: www.clovermoore.com.au/workingfor-sydney/ issues/arts-culture

Morris, A. (2018) Gentrification and Displacement: The Forced Relocation of Public Housing Tenants in Inner-Sydney. Singapore: Springer.

Németh, J. and Schmidt, S. (2011) 'The Privatization of Public Space: Modeling and Measuring Publicness'. Environment and Planning B: Planning and Design, 38(1): 5-23.

Nicholls, S. (2014) 'Onward Christian Soldier: A Premier's Faith'. Sydney Morning Herald, 26 April. Accessed online at: www.smh.com.au/nsw/onward-christiansoldier-a-premiersfaith-20140425-379pp.html

O'Connor, J. and Wynne, D. (2017) 'Introduction', in J. O'Connor and D. Wynne (eds), From the Margins to the Centre: Cultural Production and Consumption in the PostIndustrial City. Oxon, Routledge, pp. 1-15.

Parliamentary Office of Science and Technology (2005) 'Binge Drinking and Public Health'. Postnote, 244: 1-4. 
Presdee, M. (2000) Cultural Criminology and the Carnival of Crime. London, Routledge.

Putt, J. (ed.) (2010) Community Policing in Australia. Canberra, Australian Institute of Criminology.

Quilter, J. (2014) 'One-punch Laws, Mandatory Minimums and "Alcohol-Fuelled" as an Aggravating Factor: Implications for NSW Criminal Law'. International Journal for Crime, Justice \& Social Democracy, 3(1): 81-106.

Reiner, R. (2007) Law and Order: An Honest Citizen's Guide to Crime and Control. Cambridge: Polity Press.

Rief, S. (2011) Club Cultures: Boundaries, Identities and Otherness. Oxon: Routledge.

Rigakos, G. (2008) Nightclub: Bouncers, Risk, and the Spectacle of Consumption. Canada: McGill-Queen's University Press.

Roberts, M. (2015) “"A Big Night Out”: Young People's Drinking, Social Practice and Spatial Experience in the "Liminoid" Zones of English Night-time Cities'. Urban Studies, 52(3): 571-588.

Roberts, M. and Eldridge, A. (2012) Planning the Night-time City. Oxon: Routledge.

Roberts, M., Turner, C., Greenfield, S. and Osborn, G. (2006) 'A Continental Ambience? Lessons in Managing Alcohol-related Evening and Night-time Entertainment from Four European Capitals'. Urban Studies, 43(7): 1105-1125.

Rowe, D. and Lynch, R. (2012) 'Work and Play in the City: Some Reflections on the Night-time Leisure Economy of Sydney'. Annals of Leisure Research, 15(2): 132-147.

Rowe, D., Stevenson, D., Tomsen, S., Bavinton, N. and Brass, K. (2008) The City After Dark: Cultural Planning and Governance of the Night-time Economy in Parramatta. Centre for Cultural Research, University of Western Sydney.

Sanders, B. (2006) 'In the Club Redux: Ecstasy Use and Supply in a London Nightclub', in B. Sanders (ed.), Drug, Clubs and Young People - Sociological and Public Health Perspectives. Hampshire: Ashgate Publishing, pp. 122-140.

Scott, A.J. (2000) The Cultural Economy of Cities. London: Sage.

Shepherdson, P., Clancey, G., Lee, M. and Crofts, T. (2014) 'Partnerships and NSW Local Government Community Safety Officers'. Crime Prevention and Community Safety, 16(2): 71-86.

Silverstone, D. (2006) 'Pub Space, Rave Space and Urban Space: Three Different Nighttime Economies', in B. Sanders (ed.), Drugs, Clubs and Young People. Hampshire: Ashgate.

Smith, O. (2014) Contemporary Adulthood and the Night-time Economy. Houndmills: Springer.

Stevenson, D. and Paton, G. (1999) 'Representing Decline: The Role of the Arts in Framing Discourses of Deindustrialisation'. Media International Australia, 100: 129-147.

Stockwell, T., Land, E. and Rydon, P. (1993) 'High Risk Drinking Settings: The Association of Serving and Promotional Practices with Harmful Drinking'. Addiction, 88(11): 1519-1526.

Swann, R. (2019). “"Watching Out for My Boo”: Understanding Women's Aggression in a Night-time Economy'. Criminology \& Criminal Justice, 1748895819841102.

Talbot, D. (2016) Regulating the Night: Race, Culture and Exclusion in the Making of the Night-time Economy. Oxon: Routledge.

Teece, M. and Williams, P. (2000) 'Alcohol-Related Assault: Time and Place'. Trends and Issues in Crime and Criminal Justice, no. 169. Australian Institute of Criminology. 
Thomas, C.J. and Bromley, R.D.F. (2000) 'City-centre Revitalisation: Problems of Fragmentation and Fear in the Evening and Night-time City'. Urban Studies, 37(8): 1403-1429.

Tierney, J. (2006) 'We Want to be More European: The 2003 Licensing Act and Britain's Night-time Economy'. Social Policy and Society, 5(4): 453-460.

Tomsen, S. (1997) 'A Top Night: Social Protest, Masculinity and the Culture of Drinking Violence'. British Journal of Criminology, 37(1): 90-102.

Tomsen, S. (2005) 'Boozers and Bouncers: Masculine Conflict, Disengagement and the Contemporary Governance of Drinking-related Violence and Disorder'. Australian and New Zealand Journal of Criminology, 38(3): 283-297.

Tomsen, S. (2012) 'Crime and the Night-time Economy in Australia's Global City: Fear, Loathing and Neo-liberal (Non) Governance', Papers from the Australian and New Zealand Critical Criminology Conference.

Tomsen, S. (2014) 'Identity Wars. Crime, Safety and Conflict in Sydney's Nighttime Economy'. Etnografia e ricerca qualitativa, 7(3): 463-480.

Tomsen, S. (2018) 'Homicides with Direct and Indirect Links to the Night-time Economy'. Drug and Alcohol Review, 37(6): 794-801.

Tomsen, S., Homel, R. and Thommeny, J. (1991) 'The Causes of Public Violence: Situational versus Other Factors in Drinking Related Assaults', in D. Chappell, P. Grabosky and H. Strang (eds), Australian Violence: Contemporary Perspectives. Canberra: Australian Institute of Criminology.

Tomsen, S. and Payne, J. (2016) 'Homicide in the Night-time Economy'. Trends and Issues in Crime and Criminal Justice, no. 521. Australian Institute of Criminology.

Tomsen, S. and Wadds, P. (2016) 'Nightlife Ethnography, Violence, Policing and Security', in J. Stubbs and S. Tomsen (eds), Australian Violence: Crime, Criminal Justice and Beyond. Annandale: Federation.

Valverde, M. (2011) 'Seeing Like a City: The Dialectic of Modern and Premodern Ways of Seeing in Urban Governance'. Law \& Society Review, 45(2): 277-312.

Wadds, P. (2015) 'Crime, Policing and (In)Security: Press Depictions of Sydney's Night-Time Economy'. Current Issues in Criminal Justice, 27: 95-112.

Wadds, P. (2019) '“It's Not Like It Used to Be": Respect and Nostalgia in the Policing of Nightlife'. Australian \& New Zealand Journal of Criminology, 52(2): 213-230.

Wall, L. and Quadara, A. (2014) Under the Influence?: Considering the Role of Alcohol and Sexual Assault in Social Contexts. Australian Institute of Family Studies.

Wells, S. and Graham, K. (2003) 'Aggression Involving Alcohol: Relationship to Drinking Patterns and Social Context'. Addiction, 98(1): 33-42.

Wilkinson, C., Livingston, M. and Room, R. (2016) 'Impacts of Changes to Trading Hours of Liquor Licences on Alcohol-related Harm: A Systematic Review 2005-2015'. Public Health Research and Practice, 26(4): e2641644.

Winlow, S. (2001) Badfellas: Crime, Tradition and New Masculinities. New York: Berg.

Winlow, S. and Hall, S. (2006) Violent Night: Urban Leisure and Contemporary Culture. Oxford: Berg.

Wolifson, P. (2018a) “"Civilising” by Gentrifying: The Contradictions of Neoliberal Planning for Nightlife in Sydney, Australia', in J. Nofre and A. Eldridge (eds), Exploring Nightlife: Space, Society and Governance. Lanham: Rowman and Littlefield International, pp. 35-52. 
Wolifson, P. (2018b) Sydney at Night: People, Places, and Policies of a Neoliberal City. PhD Thesis, UNSW.

Wolifson, P. and Drozdzewski, D. (2017) 'Co-opting the Night: The Entrepreneurial Shift and Economic Imperative in NTE Planning'. Urban Policy and Research, 35(4): 486-504.

Wolifson, P. and Gibson, C. (2016) 'Beyond Lockouts: Sydney Needs to Become a More Inclusive City'. The Conversation, 17 March.

Wotherspoon, G. (2008) 'Economy'. Dictionary of Sydney, Accessed online at: http:// dictionaryofsydney.org/entry/economy 
While this dialogue was beneficial, it is still limited in its frequency and remains exceptional to high-profile cases.

\section{References}

Altheide, D., (2017) 'Media and Fear: After Terrorism'. Sociologia Della Comunicazione, 54: 19-39.

Amin, A. and Malmberg, A. (1995) 'Competing Structural and Institutional Influences on the Geography of Production in Europe', in A. Amin (ed.), Post-Fordism: A Reader. Oxford: Blackwell.

Anon (2009) 'Operation Unite Sends a Strong Message', Sydney Morning Herald, 13 December, Sydney Morning Herald Archives database.

Anon (2012) 'Enough is Enough with Kings Cross Lawlessness', Sydney Morning Herald, 12 July, p. 12.

Anon (2014) 'Take Violent Thugs Off Our City Streets', Daily Telegraph, 2 January, np.

Baker, J. (2008a) 'Police Get Blame for Rise in Bar Violence', Sydney Morning Herald, 24 April, p. 3

Baker, J. (2008b) 'Who Will Guard the Guardians?', Sydney Morning Herald, 16 February, p. 26.

Blackwell, E. and Watson, R. (2007) 'Just Another Drunken Night on Our Streets: OUR VIOLENT NIGHTLIFE', Daily Telegraph, 12 November, p. 11.

Boivin, R. and Cordeau, G. (2011) 'Measuring the Impact of Police Discretion on Official Crime Statistics: A Research Note'. Police Quarterly, 14: 186-203.

Bourdieu, P. (1986) 'The Forms of Capital', in J.G. Richardson (ed.), Handbook of Theory and Research for the Sociology of Education. New York: Greenwood, pp. 241-258.

Braithwaite, D. (2007) 'The Worse for Drink: Pub Violence Soars', Sydney Morning Herald, 18 September, p. 1.

Brighton, P. and Foy, D. (2007) News Values. London: Sage.

Button, M. (2002) Private Policing. Devon: Willan Publishing.

Christie, N. (1986) 'The Ideal Victim', in E. Fattah (ed.), From Crime Policy to Victim Policy. New York: St Martin's Press, pp. 17-30.

Clifton, B. (2000) 'Why Casino Patron Died', Daily Telegraph, 1 June 2000, p. 20.

Cohen, S. (1972) Folk Devils and Moral Panics: The Creation of the Mods and Rockers. St Albans: Paladin.

Cooke, J. (1998) 'Brother the "Catalyst" for Brawl', Sydney Morning Herald, 24 October 1998, p. 2.

Coote, A. (2011) 'The Fatal Footage: CCTV Shows Bashed Father Playing the Peacemaker', Daily Telegraph, 6 January 2011, p. 9.

Cornaglia, F. and Leigh, A. (2011) Crime and Mental Wellbeing. CEP Discussion Paper no. 1049, Centre for Economic Performance: London School of Economics.

Critcher, C. (2003) Moral Panics and the Media. UK: McGraw-Hill Education.

Dale, A., Davies, L. and Chambers, G. (2011) 'Court Told How Ivy's Staff Lied to Officers'. Daily Telegraph, 31 August 2011, p. 2.

Dasey, D. (2000) 'High Risk People in Security Industry', Sun Herald, 29 October 2000 , p. 43. 
Davies, L. (2008) 'Pub Violence Caused This: Bouncer Justice ... and the Real Law is Unmoved', Daily Telegraph, 29 May 2008, p. 13.

Davies, L. (2011) 'Hopoate went too far', Daily Telegraph, 20 April 2011, p. 12.

Devine, M. (2012a) 'Violence is Killing Our City', Daily Telegraph, 11 July 2012, p. 13.

Devine, M. (2012b) 'Real Crime is Police Inaction', Sunday Telegraph, 15 July 2012, p. 41.

Ditton, J., Chadee, D., Farrall, S., Gilchrist, E. and Bannister, J. (2004) 'From Imitation to Intimidation: A Note on the Curious and Changing Relationship between the Media, Crime and Fear of Crime'. British Journal of Criminology, 44(4): 595-610.

Fife-Yeomans, J. (2009a) 'Operation Unite: Times Up for Drunken Thugs', Daily Telegraph, 11 December, p. 12.

Fife-Yeomans, J. (2009b) 'RECLAIM OUR STREETS: Police Across Two Nations Unite to Fight Violence', Daily Telegraph, 19 November, p. 1.

Fife-Yeomans, J. (2011) 'Painful Decision to End a Dad's Life', Daily Telegraph, 3 January 2011, p. 1.

Fife-Yeomans, J. and Dale, A. (2011) 'Hopoate and a Trademark Presence', Daily Telegraph, 12 January 2011, p. 13.

Fife-Yeomans, J. and Morri, M. (2014) 'Every Night A Battlefield', Daily Telegraph, 3 January, p. 5.

Fishman, M. (1978) 'Crime Waves as Ideology'. Social Problems, 25(5): 531-543.

Fourcade-Gourinchas, M. and Babb, S.L. (2002) 'The Rebirth of the Liberal Creed: Paths to Neoliberalism in Four Countries'. American Journal of Sociology, 108(3): 533-579.

Frost, C. (2012) 'Young Man Senselessly Murdered in Random Act of Madness: Kings Cross Bashing', Daily Telegraph, 11 July 2012, p. 4.

Garkawe, S. (1995) 'Victims of Crime and Law and Order Ideology: A Critical Analysis'. Australian Journal of Social Issues, 30(4): 435-444.

Gilliam Jr, F.D. and Iyengar, S. (2000) 'Prime Suspects: The Influence of Local Television News on the Viewing Public'. American Journal of Political Science, 7(1): 560-573.

Greer, C. (2007) 'News Media, Victims and Crime', in P. Davies, P. Francis and C. Greer (eds), Victims, Crime and Society. London, Sage, pp. 20-50.

Greer, C. and Reiner, R. (2015) 'Mediated Mayhem: Media, Crime and Criminal Justice (5th ed.)', in M. Maguire, R. Morgan and R. Reiner (eds), Oxford Handbook of Criminology. UK: Oxford University Press, pp. 245-278.

Hall, L. (2011) 'Hopoate Guilty of Kings Cross Assault', Sydney Morning Herald, 19 April. Sydney Morning Herald database.

Hall, S., Critcher, C., Jefferson, T., Clarke, J. and Roberts, B. (1978) Policing the Crisis: Mugging, the State, and Law and Order. New York: Palgrave Macmillan.

Harvey, D. (2005) A Brief History of Neoliberalism. Oxford: Oxford University Press.

Hayes-Jonkers, C.S. (2015) Bouncers, Brutes and Brawn: Are Bouncers Being Discriminated Against in News Reports? A Critical Discourse Analysis. Doctoral dissertation, James Cook University.

Heath, L. and Gilbert, K. (1996) 'Mass Media and Fear of Crime'. American Behavioral Scientist, 39(4): 379-386.

Hills, B. (2011) 'Bash Victim's Widow Queries "Pack” Attack', The Sunday Telegraph, 9 January 2011, p. 33.

Hogg, R. and Brown, D. (1998) Rethinking Law and Order. Annandale: Pluto Press. 
Howden, S. (2011) 'Kings of the Cross Take Matters into Their Own Hands', Sydney Morning Herald, 1 August, p. 1.

Howden, S., Olding, R., Hall, L. and Munro, K. (2011) 'Cage Fighter Charged Over "Vicious" Ivy Assault', Sydney Morning Herald, 30 August 2011, p. 1.

Howden, S. and Ralston, N. (2011) 'Private Army of the Cross', The Sun Herald, 20 March, p. 19.

Innes, M. (2004) 'Signal Crimes and Signal Disorders: Notes on Deviance as Communicative Action'. British Journal of Sociology, 55(3): 335-355.

Jacobsen, G. (2004) 'Bouncer Regulations Inadequate, Says Professor, As Tragedy Sparks Calls for Industry Crackdown', Sydney Morning Herald, 21 January 2004, p. 6.

Jessop, B (1997) 'The Entrepreneurial City: Reimaging Localities, Redesigning Economic Governance or Restructuring Capital', in N. Jewson and S. MacGregor (eds), Transforming Cities: Contested Governance and New Spatial Divisions. New York: Routledge.

Jessop, B. (2002) 'Liberalism, Neoliberalism, and Urban Governance: A StateTheoretical Perspective'. Antipode, 34(3): 452-472.

Jewkes,Y. and Linnemann, T. (2017) Media and Crime in the US. Thousand Oaks: Sage.

Kamper, A. (2003) 'Alcohol Crackdown as Drink Crime Soars', Daily Telegraph, 31 March, p. 11.

Kean, M. (2014) 'Enough is Enough: Time to Stop Alcohol-fuelled Violence is Now', Daily Telegraph, 3 January, p. 13.

Kennedy, L. (2009) 'Security Bounced from Cross Clubs', Sun Herald, 22 March 2009 , p. 13.

Lamont, L. (1999) 'Call in Clayton's Cops', Sydney Morning Herald, 28 October 1999, p. 13.

Laster, K. and Erez, E. (2001) 'The Oprah Dilemma: The Use and Abuse of Victims', in D. Chappell and P. Wilson (eds), Crime and Criminal Justice in Australia: 2000 and Beyond. Sydney: Butterworths, pp. 240-258.

Lee, M. (2007) Inventing Fear of Crime: Criminology and the Politics of Anxiety. Devon: Willan Publishing.

Lee, M. (2011) 'Force Selling: Policing and the Manufacture of Public Confidence?', Proceedings from the Australian and New Zealand Critical Criminology Conference 2010.

Lee, M. and McGovern, A. (2013) 'Force to Sell: Policing the Image and Manufacturing Public Confidence'. Policing and Society, 23(2): 103-124.

Lee, M., Tomsen, S. and Wadds, P. (2020) 'Locking-out Uncertainty: Conflict and Risk in Sydney's Night-time Economy', in Pratt, J. (ed.), Criminal Justice, Risk and the Revolt against Uncertainty. Melbourne: Palgrave Macmillan.

Leishman, F. and Mason, P. (2003) Policing and the Media: Facts, Fictions and Factions. Devon: Willan Publishing.

Linnell, G. (2008) 'Booze-fuelled Crime the Biggest Problem: COPS ON THE BRINK', Daily Telegraph, 8 July, p. 5.

Mascord, S. (2005) 'Hoppa Out: Banned, Sacked, Retired', Sydney Morning Herald, 23 March 2005, p. 36.

Mawby, R.C. (2002) Policing Images: Policing, Communication and Legitimacy. Devon: Willan Publishing.

Mazerolle, L. and Ransley, J. (2005) Third Party Policing. Cambridge: Cambridge University Press. 
McGovern, A. and Lee, M. (2010) 'Cop[ying] it Sweet?: Police Media Units and the Making of News'. Australian and New Zealand Journal of Criminology, 43(3): 444-464.

Messner, M.A. (1990) 'When Bodies are Weapons: Masculinity and Violence in Sport'. International Review for the Sociology of Sport, 25(3): 203-220.

Moore, M. and McKenny, L. (2012) 'Cross Marks Spot Where Violence is All Too Common'. Sydney Morning Herald, 11 July 2012, p. 6.

Munro, P. 2014. 'Coward's Blow Symbolises New Culture of Unbounded Violence'. Sydney Morning Herald, 4 January, p. 7.

Murphy, D. (2000) 'Minister and Police Linked to Casino Gifts'. Sydney Morning Herald, 20 June 2000, p. 2.

Narushima, Y. (2008) 'Drunks Add to Social Fears'. Sydney Morning Herald, 6 February 2008, p. 3.

Nicholls, S. (2012a) 'Booze Bans Not the Answer: Minister'. Sydney Morning Herald, 17 July 2012, p. 1.

Nicholls, S. (2012b) 'Small Bars Hit Back at Rebuke by Minister'. Sydney Morning Herald, 18 July 2012, p. 2.

Nicholls, S. and McClymont, K. (2011) 'Police Consider Ivy License Restrictions'. Sydney Morning Herald, 1 September 2011, p. 3.

Nickels, E.L. (2007) 'A Note on the Status of Discretion in Police Research'. Journal of Criminal Justice, 35: 570-578.

NSW Legislative Assembly (1998) Private Member's Statements 'Death of Mr Peter Dalamangas', 24 June 1998. Available online at: www.parliament.nsw.gov.au/ Hansard/Pages/HansardResult.aspx\#/docid/HANSARD-1323879322-18025

NSW Police (2010) 'New South Wales Police Force Annual Report: Year in Review 2010'. Access online at: www.police.nsw.gov.au/_data/assets/pdf_file/0003/214977/ Annual_Report_Year_in_Review.pdf

Olding, R. (2014) 'Pressure Grows for Tougher Sentences'. Sydney Morning Herald, 4 January, np.

Olding, R. and Nicholls, S. (2011) 'Ivy Bouncer Used Licensing Loophole to Work in NSW'. Sydney Morning Herald, 2 September 2011, p. 2.

Olding, R., Munro, K., Howden, S. and McClymont, K. (2011) 'Man Beaten in Club as Security Diverted Help, Police Claim’. Sydney Morning Herald, 31 August 2011, p. 3.

Palmer, J. (2000) Spinning into Control: News Values and Source Strategies. London: Leicester University Press.

Peterson, A. (1999) 'Casino Guard's Street Justice'. Daily Telegraph, 26 February 1999, p. 24.

Potter, G.W. and Kappeler, V.E. (2006) Constructing Crime: Perspectives on Making News and Social Problems (2nd Edition). Long Grove: Waveland Press.

Presdee, M. (2000) Cultural Criminology and the Carnival of Crime. London: Routledge.

Quigley, A. (2007) 'Never-ending Violent Season Thrust upon Us', Daily Telegraph, 7 November 2007, p. 27.

Quilter, J. (2014). 'One-punch Laws, Mandatory Minimums and "Alcohol-Fuelled" as an Aggravating Factor: Implications for NSW Criminal Law'. International Journal for Crime, Justice \& Social Democracy, 3(1): 81-106.

Ralston, N. and Kwek, G. (2012) 'Unprovoked: Teen Talking on Phone Fatally Punched on First Night Out in Kings Cross', Sydney Morning Herald, 10 July. Viewed 12 July 2012, Sydney Morning Herald database. 
Ralston, N. and McKenny, L. (2012) 'Top Cop's Grim Warning for Kings Cross'. Sydney Morning Herald, 13 July 2012, p. 1.

Reiner, R., Livingstone, S. and Allen, J. (2000) “"No More Happy Endings?”: The Media and Popular Concern about Crime since the Second World War', in T. Hope and R. Sparks (eds), Crime, Risk and Insecurity: Law and Order in Everyday Life and Political Discourse. Oxon: Routledge, pp. 107-126.

Reiner, R., Livingstone, S. and Allen, J. (2013) 'From Law and Order to Lynch Mobs: Crime News since the Second World War', in P. Mason (ed.), Criminal Visions: Media Representations of Crime and Justice. Oxon: Routledge, pp. 25-44.

Ringland, C. and Baker, J. (2009) 'Is the Assault Rate in NSW Higher Now than it Was During the 1990s? An Examination of Police, Crime Victim Survey and Hospital Separation Data', Crime and Justice Bulletin no. 127, NSW Bureau of Crime Statistics and Research.

Sacco, V.F. (1995) 'Media Constructions of Crime'. Annals of the American Academy of Political and Social Science, 539: 141-154.

Sikora, K. (2008) 'We Are Living in Fear of Drunken Violence'. Daily Telegraph, 15 April, p. 11.

Stoddart, B. and Sandiford, K.A.P. (eds) (1998) The Imperial Game: Cricket, Culture and Society. Manchester: Manchester University Press.

Surette, R. (1992) Media, Crime, and Criminal Justice: Images and Realities. Pacific Grove: Brooks/Cole Publishing Company.

Tomsen, S. (2005) 'Boozers and Bouncers: Masculine Conflict, Disengagement and the Contemporary Governance of Drinking-related Violence and Disorder'. Australian and New Zealand Journal of Criminology, 38(3): 283-297.

Tomsen, S. (2012) 'Crime and the Night-time Economy in Australia's Global City: Fear, Loathing and Neo-Liberal (Non) Governance'. Papers from the Australian and New Zealand Critical Criminology Conference.

Tomsen, S., Homel, R. and Thommeny, J. (1991) 'The Causes of Public Violence: Situational versus Other Factors in Drinking Related Assaults', in D. Chappell, P. Grabosky and H. Strang (eds), Australian Violence: Contemporary Perspectives. Canberra, Australian Institute of Criminology.

Tomsen, S. and Wadds, P. (2016) 'Nightlife Ethnography, Violence, Policing and Security', in J. Stubbs and S. Tomsen (eds), Australian Violence: Crime, Criminal Justice and Beyond. Annandale, Australia: Federation Press.

Van Den Broeke, L. (2012) 'Crossing the Line into Danger Zone'. Daily Telegraph, 14 July 2012, p. 4.

Victorian Legislative Assembly (2004) 'Private Security Bill', Second Reading, 11 May, 2004. Available online at: http://hansard.parliament.vic.gov.au/isysquery/77b7f2a8e950-4206-b01d-f1c47b1cc962/11/doc/

Wadds, P. (2019) “"It's Not Like It Used to Be": Respect and Nostalgia in the Policing of Nightlife'. Australian \& New Zealand Journal of Criminology, 52(2): 213-230.

Walker, F. (1999) 'Thugs Lay it on the Line: Train Security is Being Fast-tracked and Night Travellers Know Why'. Sun Herald, 8 August, p. 15.

Weatherburn, D. (2011) 'The Uses and Abuses of Crime Statistics'. Contemporary Issues and Crime and Justice no. 153. NSW Bureau of Crime Statistics and Research. 
Weaver, C. (2010) 'FACT: This year 65,000 of Us Will Be Hospitalised from Alcohol-related Injuries'. Sunday Telegraph, 7 March 2010, p. 2.

Weber, S. (2010) 'Last Orders for Drunken Aggression'. Sydney Morning Herald, 9 November, p. 3.

Weber, S. (2012) 'Time to Call Time on Boozy Violence'. Daily Telegraph, 12 July 2012, p. 24.

Welch, D. (2008a) 'Police Chiefs Call for War on Drunks'. Sydney Morning Herald, 28 May, p. 3.

Welch, D. (2008b) 'Police Get Tough on Alcohol'. Sydney Morning Herald, 4 October, p. 8.

White, N. (2014) 'Tale of Two-Cities: Quiet in Newcastle, But Chaos Reigns in the Cross'. Daily Telegraph, 12 January, np. 
exists in parts of the security industry. In one conversation, Charlie noted a fear of retribution for any information given about other venue doorstaff and showed his reluctance in assisting police with matters that did not directly concern him:

I was there the night there was the shooting at [a nightclub] across the road [in Kings Cross]. I was actually in the laneway when the shooting happened, and it was more of a gunshot - you look up and people are coming towards you so you just sort of put your head down and look at the wall, because technically I didn't see anything, and that's how it was. The police came around the next day and we gave them footage from our cameras, and I was actually asked, "Why did you put your head down?" I said, "Look, I didn't see anything." Simple as that. I must say, I did not know the people who were involved, but it was more of a - you see something and you implicate yourself. From what I've learned, you really do just keep to yourself. It's better that way.

(Charlie)

This incident was an outstanding example of the failed communication and flawed rapport between police and security in a serious matter that was more isolated than the everyday interaction between the two groups. However, it signalled one of the major difficulties confronting the police and, more generally, those concerned with regulating and preventing criminal behaviour in Sydney's NTE. As two segments of the policing occupation, it is worrying that communication was limited due to fear of reprisal from within the security sector. While conscious efforts have been made to improve the working relationship between the two parties, Charlie's comments indicate that there is still a long way to go.

\section{References}

Butler, J. (1990) Gender Trouble. London: Routledge.

Connell, R.W. (1995) Masculinities. Berkeley: University of California Press.

Erickson, B.H., Albanese, P. and Drakulic, S. (2000) 'Gender on a Jagged Edge: The Security Industry, its Clients, and the Reproduction and Revision of Gender'. Work and Occupations, 27(3): 294-318.

Fileborn, B., Wadds, P. and Tomsen, S. (2020) 'Sexual Harassment and Violence at Australian Music Festivals: Reporting Practices and Experiences of Festival Attendees'. Australian \& New Zealand Journal of Criminology, DOI: 0004865820903777

Hadfield, P. (2008) 'From Threat to Promise: Nightclub "Security", Governance and Consumer Elites'. British Journal of Criminology, 48: 429-447.

Hobbs, D. (1988) Doing the Business: Entrepreneurship, the Working Class, and Detectives in the East End of London. Oxford: Clarendon Press.

Hobbs, D., Hadfield, P., Lister, S. and Winlow, S. (2002) 'Door Lore: The Art and Economics of Intimidation'. British Journal of Criminology, 42: 352-370. 
Hobbs, D., Hadfield, P., Lister, S. and Winlow, S. (2003) Bouncers: Violence and Governance in the Night-time Economy. Oxford: Oxford University Press.

Hobbs, D., Hadfield, P., Lister, S. and Winlow, S. (2005) 'Violent Hypocrisy: Governance and the Night-time Economy'. European Journal of Criminology, 2(2): 161-183.

Hobbs, D., O’Brien, K. and Westmarland, L. (2007) 'Connecting the Gendered Door: Women, Violence and Doorwork'. The British Journal of Sociology, 58(1): 21-38.

Hughes, E.C. (1962) 'Good People and Dirty Work'. Social Problems, Vol. X.

Johnston, L. (1992) The Rebirth of Private Policing. London: Routledge.

Messerschmidt, J. (1997) Crime as Structured Action: Gender, Race, Class, and Crime in the Making. Thousand Oaks: Sage.

Messerschmidt, J.W. (2018) Hegemonic Masculinity: Formulation, Reformulation, and Amplification. Maryland: Rowman \& Littlefield.

Miller P., Pennay, A., Droste, N., Jenkinson, R., Quinn, B., Chikritzhs, T., Tomsen, S., Wadds, P., Jones, S., Palmer, D., Barrie, L., Lam, T., Gilmore, W. and Lubman, D. (2013) Patron Offending and Intoxication in Night-time Entertainment Districts (POINTED): Final Report. Melbourne: NDLERF.

Monaghan, L.F. (2002) 'Regulating "Unruly Bodies": Work Tasks, Conflict and Violence in Britain's Night-time Economy'. British Journal of Sociology, 53(3): 403-429.

Monaghan, L.F. (2008) 'Hard Men, Shop Boys and Others: Embodying Competence in a Masculinist Occupation', in S. Tomsen (ed.), Crime, Criminal Justice and Masculinities. Hampshire: Ashgate Publishing Limited.

Rigakos, G. (2008) Nightclub: Bouncers, Risk, and the Spectacle of Consumption. Canada: McGill-Queen's University Press.

Tomsen, S., Homel, R. and Thommeny, J. (1991) 'The Causes of Public Violence: Situational versus Other Factors in Drinking Related Assaults', in D. Chappell, P. Grabosky and H. Strang (eds), Australian Violence: Contemporary Perspectives. Canberra, Australian Institute of Criminology.

Tomsen, S. (2005) 'Boozers and Bouncers: Masculine Conflict, Disengagement and the Contemporary Governance of Drinking-related Violence and Disorder'. Australian and New Zealand Journal of Criminology, 38(3): 283-297.

Wadds, P. (2020) 'Fear and Loathing in the Cross: Researching the Policing of Nightlife in Sydney', in P. Wadds, N. Apoifis, S.Schmeidl and K. Spurway (eds), Navigating Fieldwork in the Social Sciences: Stories of Danger, Risk and Reward. London: Palgrave Macmillan.

Wells, S., Graham, K. and Purcell, J. (2009) 'Policy Implications of the Widespread Practice of "Pre-drinking" or "Pre-gaming" Before Going to Public Drinking Establishments Are Current Prevention Strategies Backfiring?'. Addiction, 104(1): 4-9.

West, C. and Zimmerman, D. (1987) 'Doing Gender'. Gender and Society, 1(2): 125-151. Winlow, S. (2001) Badfellas: Crime, Tradition and New Masculinities. New York: Berg. 
sanctions by deliberately avoiding police attention and preferring creative inhouse solutions that contrast sharply with the historical indifference towards victims:

Security guards are rectifying assaults and brawls themselves, sending people home in a taxi with vouchers, telling them to come back the next day, bribing them off with food, accommodation, drinks, so it doesn't go reported, and it doesn't come up on the stats.

(Stuart)

The regulatory mechanisms employed in NSW since 2008 have repeatedly been referred to as highly successful due to improvements of the measured performance of listed venues. Yet there were serious flaws in their grassroot effects and the contentious fixation with 'recorded' incidents that often limited the true effectiveness of them.

\section{References}

AAP (2005) 'NSW Police to Appeal After Swearing Case Thrown Out', Australian Associated Press General News, 18 October, np.

Brown, D., Farrier, D., McNamara, L., Steel, A., Grewcock, M., Quilter, J. and Schwartz, M. (2015). Criminal Laws: Materials and Commentary on Criminal Law and Process in New South Wales (Sixth Edition). Annandale: The Federation Press.

Burgess, M. and Moffatt, S. (2011) 'The Association Between Alcohol Outlet Density and Assaults on and Around Licensed Premises'. Crime and Justice Bulletin no. 147, NSW Bureau of Crime Statistics and Research.

Chan, J. (1997) Changing Police Culture: Policing in a Multicultural Society. Cambridge: Cambridge University Press.

City of Sydney (2019) 'Walking Count Data'. Available online at: https://data.cityofsydney. nsw.gov.au/datasets/walking-count-surveys

Crawford, A. (2013) 'The Police, Policing and the Future of the "Extended Policing Family"', in J. Brown (ed.), The Future of Policing. Oxon: Routledge, pp. 173-190.

Crawford, A., Lister, S., Blackburn, S. and Burnett, J. (2005) Plural Policing: The Mixed Economy of Visible Patrols in England and Wales. Bristol: Policy Press.

Cunneen, C. (2001) Conflict, Politics and Crime: Aboriginal Communities and the Police. Sydney: Allen \& Unwin.

Dixon, D. (1999) A Culture of Corruption: Changing an Australian Police Service. Sydney: Hawkins Press.

Donnelly, N., Poynton, S., Weatherburn, D., Bamford, E. and Nottage, J. (2006) 'Liquor Outlet Concentrations and Alcohol-Related Neighbourhood Problems'. Alcohol Studies Bulletin no. 8, NSW Bureau of Crime Statistics and Research.

Donnelly, N., Scott, L., Poynton, S., Weatherburn, D., Shanahan, M. and Hansen, F. (2007) 'Estimating the Short-Term Cost of Police Time Spent Dealing with Alcohol-Related Crime in NSW'. Monograph Series no. 25. Hobart, National Drug Law Enforcement Research Fund. 
Doran, C., Wadds, P., Shakeshaft, A. and Tran, D.A. (2020) Evaluation of the Take Kare Safe Space Program: Final Report. Sydney, NSW Department of Justice.

Dunn, M. and Degenhardt, L. (2009) 'The Use of Drug Detection Dogs in Sydney, Australia'. Drug and Alcohol Review, 28(6): 658-662.

Finnane, M. (1994) Police and Government: Histories of Policing in Australia. Melbourne: Oxford University Press.

Fleming, J. (2010) 'Learning to Work Together: Police and Academics'. Policing: A Journal of Policy and Practice, 4(2): 139-145.

Fox, J. and Lundman, R. (1974) 'Problems and Strategies in Gaining Access in Police Organisations'. Criminology, 12: 52-69.

Goh, D. and Ramsey, S. (2019) 'An Update of Long-term Trends in Property and Violent Crime in New South Wales: 1990-2018'. Crime and Justice Statistics Brief Issue no. 139, NSW Bureau of Crime Statistics and Research.

Harris, A. (2012) 'Cops Quitting in Droves: More than a Third of Officers Have Less than 10 Years' Experience', News.com.au, 6 February, np.

Horn, R. (1997) 'Not "One of the Boys": Women Researching the Police'. Journal of Gender Studies, 6(3): 297-308.

Hughes, C.E., Ritter, A., Lancaster, K. and Hoppe, R. (2017) 'Understanding Policy Persistence - The Case of Police Drug Detection Dog Policy in NSW, Australia'. International Journal of Drug Policy, 44: 58-68.

Humphries, D. (2011) 'Punch Drunk and Looking for Answers', Sydney Morning Herald, 3 September, np. Available online at: www.smh.com.au/national/nsw/ punch-drunk-and-looking-for-answers-20110902-1jpzw.html

Johnston, L. (2003) 'From "Pluralisation" to "the Police Extended Family": Discourses on the Governance of Community Policing in Britain', International Journal of the Sociology of Law, 31: 185-204.

Johnston, L. (2007) “"Keeping the Family Together". Police Community Support Officers and the "Police Extended Family in London". Policing \& Society, 17(2): 119-140.

Kraska, P.B. (2007) 'Militarization and Policing - Its Relevance to 21st Century Police'. Policing: A Journal of Policy and Practice, 1(4): 501-513.

Lancaster, K., Hughes, C. and Ritter, A. (2017) “"Drug Dogs Unleashed”: An Historical and Political Account of Drug Detection Dogs for Street-level Policing of Illicit Drugs in New South Wales, Australia'. Australian \& New Zealand Journal of Criminology, 50(3): 360-378.

Manning, P.K. (1978) 'The Police: Mandate, Strategies, and Appearances', in P.K. Manning and Van Maanen, J. (eds), Policing: A View from the Street. Santa Monica: Goodyear.

McCulloch, J. (2001) Blue Army: Paramilitary Policing in Australia. Melbourne: Melbourne University Press.'

McGovern, A. (2011) 'Negotiating Access to the NSW Police Media Unit: A Personal Research Experience', in L. Bartels and K. Richards (eds), Qualitative Criminology: Stories from the Field. Sydney: Hawkins Press.

Methven, E. (2018) 'A Little Respect: Swearing, Police and Criminal Justice Discourse'. International Journal for Crime, Justice and Social Democracy, 7(3): 58-74. 
Moffatt, S. and Poynton, S. (2006) 'Long-term Trends in Property and Violent Crime in New South Wales: 1990-2004'. Crime and Justice Bulletin no. 8, NSW Bureau of Crime Statistics and Research.

Morcombe, J. (2016) 'Despite Recruits, Association Says Officer Number Across Sydney Commands Are "Far Less than They Should Be", Daily Telegraph, 25 August, np.

Murphy, D. (2005) 'Giving Manners the Finger', Sydney Morning Herald, 22 October, p. 31.

Nixon, C. (1993) 'The History of Women in the Police Service', in S. McKillop and P. Weiser Easteal (eds), Women and the Law. Conference proceedings series no. 16. Canberra: Australian Institute of Criminology.

NSW Ombudsman (2009) Review of the Impact of Criminal Infringement Notices on Aboriginal Communities.

Putt, J. (ed.) (2010) Community Policing in Australia. Canberra, Australian Institute of Criminology.

Reiner, R. (2000) The Politics of the Police. Oxford: Oxford University Press.

Ringland, C. and Baker, J. (2009) 'Is the Assault Rate in NSW Higher Now than it Was During the 1990s? An Examination of Police, Crime Victim Survey and Hospital Separation Data', Crime and Justice Bulletin no. 127, NSW Bureau of Crime Statistics and Research.

Sutton, J. (1996) 'Keeping the Faith: Women in Policing a New South Wales Perspective'. Paper presented to the First Australasian Women Police Conference Australian Institute of Criminology Conference, Sydney, July 29-31 1996. Available online at: http://citeseerx. ist.psu.edu/viewdoc/download?doi=10.1.1.518.4067\&rep=rep1\&type=pdf

Tomsen, S., Homel, R. and Thommeny, J. (1991) 'The Causes of Public Violence: Situational versus Other Factors in Drinking Related Assaults', in D. Chappell, P. Grabosky and H. Strang (eds), Australian Violence: Contemporary Perspectives. Canberra, Australian Institute of Criminology.

Winlow, S. and Hall, S. (2006) Violent Night: Urban Leisure and Contemporary Culture. Oxford: Berg.

Wood, J. (1997) Royal Commission into the NSW Police Service, Final Report, Volume I: Corruption. Sydney: Government Printer. 
The often brittle masculinities of both security and police were challenged by the unwanted public presence of the other, and frequently resulted in mistrust and animosity. This dysfunctional relationship has been and continues to be a major challenge to the effective policing of the city after dark. Furthermore, the tension between these views of public and private police are a mirror of the much wider contradiction between the contemporary state's guarantees of citizen safety, security and regulatory control, and private industry's desire for greater profits from expanded drinking and spending in a nocturnal city economy of directed and intensified consumer leisure. In the next phase of Sydney's NTE that began with the partial removal of lockout laws in early 2020, the promise of greater enjoyment and freedom must be balanced by due consideration of drinking-related harm and the rejection of any simple claim that nightlife, security and revellers can effectively self-regulate.

\section{References}

Atkinson, R. and Bridge, G. (2005) 'Introduction', in R. Atkinson and G. Bridge (eds), Gentrification in a Global Context: The New Urban Colonialism. Oxon: Routledge, pp. 1-17.

Atkinson, R. and Millington, G. (2018) Urban Criminology: The City, Disorder, Harm and Social Control. Oxon: Routledge.

Bradley T. (2017) 'The Pluralisation of Policing', in A. Deckert and R. Sarre (eds), The Palgrave Handbook of Australian and New Zealand Criminology, Crime and Justice. Melbourne: Palgrave Macmillan.

Crawford, A., Lister, S. Blackburn, S. and Burnett, J. (2005) Plural Policing: The Mixed Economy of Visible Patrols in England and Wales. Bristol: Policy Press.

Christie, N. (1986) 'The Ideal Victim', in E. Fattah (ed.), From Crime Policy to Victim Policy. New York: St Martin's Press, pp. 17-30.

Debord, G. (1983) Society of the Spectacle. Detroit: Black \& Red.

Dertadian, G.C. and Tomsen, S. (2019) 'The Case for a Second Safe Injecting Facility (SIF) in Sydney'. Current Issues in Criminal Justice, 1-13, DOI: 10.1080/10345329. 2019.1689787

Gottdiener, M. (2000) New Forms of Consumption: Consumers, Culture, and Commodification. Oxford: Rowman \& Littlefield.

Harvey, D. (2003) 'The Right to the City'. International Journal of Urban and Regional Research, 27(4): 939-941.

Hobbs, D., Hadfield, P., Lister, S. and Winlow, S. (2003) Bouncers:Violence and Governance in the Night-time Economy. Oxford: Oxford University Press.

Lister, S., Hobbs, D., Hall, S. and Winlow, S. (2000) 'Violence in the Night-time Economy; Bouncers: The Reporting, Recording and Prosecution of Assaults'. Policing and Society, 10(4): 383-402.

Loader, I. (2000) 'Plural Policing and Democratic Governance'. Social E Legal Studies, 9(3): 323-345.

Melbin, M. (1987) Night as Frontier: Colonizing the World After Dark. New York: The Free Press. 
Messerschmidt, J. (1997) Crime as Structured Action: Gender, Race, Class, and Crime in the Making. Thousand Oaks: Sage.

Quilter, J. (2014) 'One-punch Laws, Mandatory Minimums and "Alcohol-Fuelled" as an Aggravating Factor: Implications for NSW Criminal Law'. International Journal for Crime, Justice \& Social Democracy, 3(1): 81-106.

Rigakos, G. (2008) Nightclub: Bouncers, Risk, and the Spectacle of Consumption. Canada: McGill-Queen's University Press.

Rogers, C. (2017) Plural Policing: Theory and Practice. Bristol: Bristol University Press.

Sylvestre, M., Blomley, N. and Bellot, C. (2020) Red Zones: Criminal Law and the Territorial Governance of Marginalized People. Cambridge: Cambridge University Press.

Tomsen, S. (2005) 'Boozers and Bouncers: Masculine Conflict, Disengagement and the Contemporary Governance of Drinking-related Violence and Disorder'. Australian and New Zealand Journal of Criminology, 38(3): 283-297.

Tomsen, S. (2014) 'A Dangerous Proximity: The Night-time Economy and the City's Early Morning'. Lo Squaderno: Explorations in Space and Society, 32: 36-40.

Wadds, P. (2015) 'Crime, Policing and (In)Security: Press Depictions of Sydney's Night-time Economy'. Current Issues in Criminal Justice, 27(1): 95-112.

Wadds, P. (2019) “"It's Not Like It Used to Be": Respect and Nostalgia in the Policing of Nightlife'. Australian \& New Zealand Journal of Criminology, 52(2): 213-230.

Winlow, S. (2001) Badfellas: Crime, Tradition and New Masculinities. New York: Berg.

Wolifson, P. and Drozdzewski, D. (2017) 'Co-opting the Night: The Entrepreneurial Shift and Economic Imperative in NTE Planning'. Urban Policy and Research, 35(4): 486-504. 